\title{
Targeting Leishmania major Antigens to Dendritic Cells In Vivo Induces Protective Immunity
}

\author{
Ines Matos, Olga Mizenina, Ashira Lubkin, Ralph M. Steinman ${ }^{9} \dagger$, Juliana Idoyaga*9
}

Laboratory of Cellular Physiology and Immunology and Chris Browne Center for Immunology and Immune Diseases, The Rockefeller University, New York, New York, United States of America

\begin{abstract}
Efficient vaccination against the parasite Leishmania major, the causative agent of human cutaneous leishmaniasis, requires development of type 1 T-helper (Th1) $\mathrm{CD}^{+} \mathrm{T}$ cell immunity. Because of their unique capacity to initiate and modulate immune responses, dendritic cells (DCs) are attractive targets for development of novel vaccines. In this study, for the first time, we investigated the capacity of a DC-targeted vaccine to induce protective responses against $L$. major. To this end, we genetically engineered the N-terminal portion of the stress-inducible 1 protein of L. major (LmSTI1a) into anti-DEC205/ CD205 (DEC) monoclonal antibody (mAb) and thereby delivered the conjugated protein to DEC ${ }^{+}$DCs in situ in the intact animal. Delivery of LmSTI1a to adjuvant-matured DCs increased the frequency of antigen-specific CD4 ${ }^{+} \mathrm{T}_{\text {cells }}$ producing IFN- $\gamma^{+}, \mathrm{IL}-2^{+}$, and TNF- $\alpha^{+}$in two different strains of mice (C57BL/6 and Balb/c), while such responses were not observed with the same doses of a control Ig-LmSTI1a mAb without receptor affinity or with non-targeted LmSTI1a protein. Using a peptide library for LmSTI1a, we identified at least two distinct CD4 ${ }^{+} \mathrm{T}$ cell mimetopes in each MHC class II haplotype, consistent with the induction of broad immunity. When we compared T cell immune responses generated after targeting DCs with LmSTI1a or other L. major antigens, including LACK (Leishmania receptor for activated C kinase) and LelF (Leishmania eukaryotic ribosomal elongation and initiation factor 4a), we found that LmSTI1 a was superior for generation of IFN- $\gamma$-producing $C D 4^{+}$T cells, which correlated with higher protection of susceptible Balb/c mice to a challenge with $L$. major. For the first time, this study demonstrates the potential of a DC-targeted vaccine as a novel approach for cutaneous leishmaniasis, an increasing public health concern that has no currently available effective treatment.
\end{abstract}

Citation: Matos I, Mizenina O, Lubkin A, Steinman RM, Idoyaga J (2013) Targeting Leishmania major Antigens to Dendritic Cells In Vivo Induces Protective Immunity. PLoS ONE 8(6): e67453. doi:10.1371/journal.pone.0067453

Editor: Simona Stager, INRS - Institut Armand Frappier, Canada

Received February 5, 2013; Accepted May 18, 2013; Published June 26, 2013

Copyright: (c) 2013 Matos et al. This is an open-access article distributed under the terms of the Creative Commons Attribution License, which permits unrestricted use, distribution, and reproduction in any medium, provided the original author and source are credited.

Funding: The authors have no support or funding to report.

Competing Interests: The authors have declared that no competing interests exist.

* E-mail: ijuliana@rockefeller.edu

9 These authors contributed equally to this work.

$\uparrow$ Deceased.

\section{Introduction}

Leishmaniases are a spectrum of diseases caused by different species of Leishmania spp. parasites, with clinical presentation ranging from a fatal visceral form $(L$. donovani) to a localized selfhealing cutaneous lesion (L. major) [1]. In humans, acquired resistance to $L$. major infection is primarily mediated by cellular immunity, particularly antigen-specific Thl $\mathrm{CD}^{+} \mathrm{T}$ cells [2]. Similarly, Th1-dependent protection is observed in mouse experimental models of $L$. major infection [3]. Resistant strains, such as C57BL/6, develop Thl immune responses producing high levels of gamma interferon (IFN- $\gamma$ ), resulting in self-healing $[3,4,5]$. In contrast, Balb/c mice develop a typical Th2 response producing high amounts of IL-4, which is accompanied by disease progression after infection [6]. In susceptible Balb/c mice, protective Th1 $\mathrm{T}$ cell responses can be promoted by immunization $[7,8,9,10,11,12]$, suggesting that vaccines capable of generating potent and broad $\mathrm{Th} 1 \mathrm{~T}$ cell responses can provide protective immunity to Leishmania infection. However, despite current evaluation of several strategies as potential candidates, there is no licensed vaccine available against Leishmania [13].
Dendritic cells (DCs) are highly specialized antigen-presenting cells essential for generation of protective $\mathrm{T}$ cell immune responses $[14,15]$. Depending on the nature of the microbial stimulus, they can direct the development of polarized Th responses [16]. Thus, manipulation of the DC compartment for generation of antigenspecific Thl $\mathrm{T}$ cell responses offers a promising strategy for vaccination against Leishmania. Accordingly, infusion of susceptible Balb/c mice with DCs loaded ex vivo with L. major antigens induces protective Th1 $\mathrm{T}$ cell responses $[7,17,18,19]$. An alternative approach in the intact animal is the use of monoclonal antibodies (mAbs) against surface uptake receptors to deliver specific antigens to DCs in situ, within lymphoid tissues. Delivery of vaccine proteins within mAbs increases the efficiency of antigen presentation on MHC class II complexes by approximately 100-fold [20,21,22,23,24]. Importantly, DCs targeted with anti-receptor mAbs can induce protective Thl CD $4^{+} \mathrm{T}$ cell responses when an appropriate adjuvant is coadministered $[24,25,26]$. In particular, we have shown that the synthetic form of viral double-stranded RNA, polyinosinic:polycytidylic acid (poly IC), and its more RNase-resistant analog stabilized with poly-L-lysine, poly ICLC, are superior adjuvants for generation of Thl $\mathrm{T}$ cell responses induced by DC-targeted vaccines [26]. Hence, delivery of viral or 
bacterial antigens to DCs using fusion mAbs against DEC205/ CD205 (DEC) coadministered with poly IC or poly ICLC results in $\mathrm{Th} 1 \mathrm{CD}^{+} \mathrm{T}$ cell responses that protect mice against recombinant vaccinia virus expressing gag-p24 or the bacterium Yersinia pestis, respectively [22,25,27,28].

In the present study, we, for the first time, examined the potential of targeting DCs in vivo for induction of protective Th1 T cell immune responses against the parasite $L$. major. We initially focused our DC-targeting approach to the stress-inducible 1 antigen, an intracellular protein of L. major (LmSTl1) [29]. Evidence suggesting LmSTI1 is a good candidate for a protective vaccine includes the following: First, LmSTI1-specific Th1 T cells are found in draining lymph nodes of $L$. major-infected Balb/c mice [30]; second, high doses of soluble LmSTI1 protein or LmSTI1encoding DNA, coadministered with IL-12, induce protection against L. major infection [31]; and third, Leish-111f (or LEISHF1), a single recombinant poly-protein containing LmSTI, induces Thl $\mathrm{T}$ cell responses when administered with monophosphoryl lipid A (MPL) [32,33] and has been recently shown to be safe and well tolerated in human subjects [34]. Our results demonstrated that delivery of the N-terminal domain of LmSTI1 to DCs in combination with DG maturation stimuli induced potent and broad antigen-specific $\mathrm{CD} 4^{+} \mathrm{T}$ cell responses and was able to protect susceptible Balb/c mice against a subsequent challenge with $L$. major. When we compared immune responses and protection induced by targeting LmSTIl to DCs with the delivery of other Leishmania antigens, including LACK and LeIF, we found that LmSTIla was superior for generation of IFN- $\gamma$ producing $\mathrm{CD}^{+} \mathrm{T}$ cells, which correlated with higher protection against a $L$. major challenge. Taken together, our study describes a novel strategy to induce consistent and highly effective immunity to the intracellular pathogen $L$. major and thus provides a promising new tool for a DC-based vaccine.

\section{Results}

\section{LmSTI1, an Antigenic Protein Conserved between Species of Leishmania, can be Introduced into Anti- mouse DEC mAb}

Thl immune responses play a critical role in controlling leishmaniasis, and thus, antigens presented to T cells in MHC class II complexes have been considered good candidates for vaccines. An ideal vaccine antigen against Leishmania is expected to be conserved across different parasite species. Accordingly, the amino acid sequence of STI1 from L. major (LmSTI1) is $>90 \%$ conserved with the STI1 sequence in $L$. braziliensis, $L$. infantum, and $L$. donovani (Figure S1), causative agents of mucocutaneous or visceral leishmaniasis, respectively. Furthermore, LmSTI1 lacks homology with mammalian proteins (not shown), which is desirable for a vaccine antigen to prevent unwanted autoimmune responses.

The LmSTI1 protein was initially cloned in frame into the heavy chain of anti-mouse DEC mAb; however, it was highly unstable and poorly expressed. Therefore, LmSTIl was cleaved using an internal NotI site to yield a larger N-terminal portion (aa 1-398, LmSTIla) and a smaller C-terminal portion (aa 401-546, LmSTIlb) (Figure S2A), which were both cloned in frame into anti-mouse DEC mAb and a control Ig $\mathrm{mAb}$ that has no receptor affinity (Figure S2B). The fusion mAbs were successfully expressed in 293T cells and purified in protein G columns. Because of the insertion of LmSTIla or LmSTI1b, the heavy chain of the fused mAb was approximately 100 or $70 \mathrm{kDa}$, respectively, as shown by Coomassie blue staining (Figure S2G) and Western blotting (Figure S2D). Importantly, fusion of LmSTI1a or LmSTI1b into anti-DEC mAbs did not disrupt antibody function, as both anti-
DEC-LmSTIla and anti-DEC-LmSTIlb mAb efficiently bound to their corresponding receptor on stably transfected $\mathrm{CHO}$ cells but not to nontransfected CHO NEO cells (Figure S2E). Thus, anti-DEC mAb can be successfully engineered to express the LmSTI1 antigen from L. major. For our initial characterization of immune responses, LmSTIla (N-terminal domain) was used, given that it covers approximately $72 \%$ of the native protein.

\section{Anti-DEC-LmSTI1a mAb Administered with a DC Maturation Stimulus Induces Multifunctional Th1 $\mathrm{CD}^{+} \mathrm{T}$ cells}

To determine $\mathrm{T}$ cell responses induced by LmSTIla targeted to DCs via anti-DEG $\mathrm{mAb}$, we inoculated C57BL/6 mice $\left(\mathrm{H}-2^{\mathrm{b}}\right)$ with $1 \mu \mathrm{g}$ of $\mathrm{mAb}$ along with $50 \mu \mathrm{g}$ poly ICLC and $25 \mu \mathrm{g}$ antiCD40 mAb (Adjuvant, Adj) as a DC maturation stimulus [22,24]. As a control, we used Ig-LmSTIla mAb with no receptor affinity. Two weeks after immunization, antigen-specific immune responses were evaluated by measuring IFN- $\gamma$-production in response to a reactive LmSTIla peptide mix by multicolor flow cytometry. As shown in Figure $1 \mathrm{~A}$ and quantified in Figure 1B, delivery of LmSTIla within DEG mAb induced IFN- $\gamma$-producing $\mathrm{CD}^{+} \mathrm{T}$ cells. The frequency of the IFN- $\gamma^{+} \mathrm{CD} 4^{+} \mathrm{T}$ cells was greater when LmSTIla was delivered using anti-DEC mAb compared with control Ig-LmSTIla mAbs (Figure 1, A and B). These CD $4^{+} \mathrm{T}$ cells were antigen-specific since they only produced IFN- $\gamma$ in response to $\mathrm{LmSTIl}$ a reactive peptide mix but not in response to a negative control LeIF peptide mix (Figure 1, A and B).

Previous studies revealed that protection against L. major infection in mice [35] and healing of cutaneous leishmaniasis in humans [36] correlates with the priming of multifunctional Thl $\mathrm{CD}^{+} \mathrm{T}$ cells that simultaneously secrete high amounts of IFN- $\gamma$, IL-2, and TNF- $\alpha$. Thus, we examined the capacity of LmSTIlaspecific IFN $\gamma^{+} \mathrm{CD}^{+} \mathrm{T}$ cells to produce other cytokines. Following immunization with anti-DEC-LmSTIla mAb, approximately $70 \%$ of the IFN- $\gamma$-producing $\mathrm{CD} 4^{+} \mathrm{T}$ cells, accounting for approximately $2-3 \%$ of the total $\mathrm{CD} 4^{+}$cells, also produced IL-2 and TNF- $\alpha$ (Figure 1C). Furthermore, $\mathrm{CD}^{+} \mathrm{T}$ cells producing three cytokines, i.e., IFN- $\gamma$, IL-2, and TNF- $\alpha$, had the highest median fluorescence intensity (MFI) for IFN- $\gamma$ compared with $\mathrm{T}$ cells producing only 1-2 cytokine (Figure 1D). This last parameter has also been associated with protective immunity to Leishmania infection $[35,36]$.

We then performed similar experiments in susceptible Balb/c $\left(\mathrm{H}-2^{\mathrm{d}}\right)$ mice, which typically develop a Th2 response to $L$. major infection. Anti-DEC-LmsTIla mAb induced significantly higher percentage of antigen-specific IFN- $\gamma$-producing $\mathrm{CD} 4^{+} \mathrm{T}$ cells than control Ig-LmSTIla mAb (Figure 1E), and the majority of these IFN- $\gamma^{+} \mathrm{CD}^{+} \mathrm{T}$ cells also produced TNF- $\alpha$ and IL-2 (Figure S3). Moreover, $\mathrm{CD} 4^{+} \mathrm{T}$ cells from mice immunized with anti-DEC$\mathrm{LmSTIla} \mathrm{mAb}$ proliferated vigorously in vitro in response to the reactive LmSTIla peptide mix and were able to produce higher amounts of IFN- $\gamma$ after a second restimulation (Figure 1F).

Overall, these results show that delivery of LmSTIla via antiDEG $\mathrm{mAb}$ is effective at inducing significantly higher frequencies of antigen-specific $\mathrm{CD} 4^{+} \mathrm{T}$ cells producing elevated levels of three Thl cytokines in two different MHC II haplotypes, $\mathrm{H}-2^{\mathrm{b}}$ and $\mathrm{H}-$ $2^{\mathrm{d}}$. These features, i.e., multifunctionality, high cytokine production, and proliferation abilities, have been associated with generation of protective $\mathrm{T}$ cell immunity to cutaneous leishmaniasis. 
A
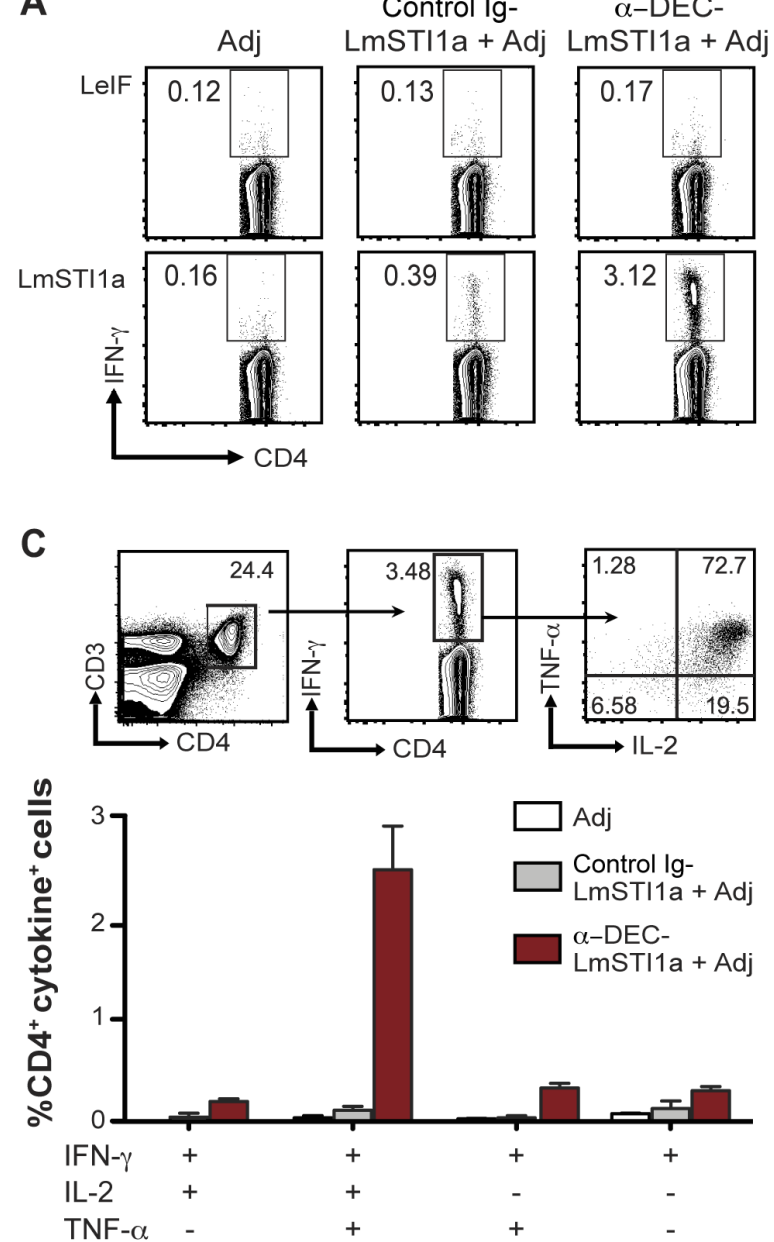

E

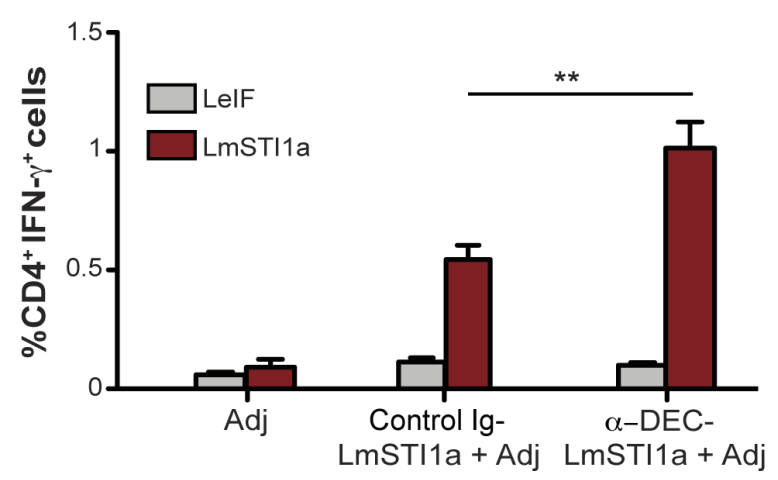

B

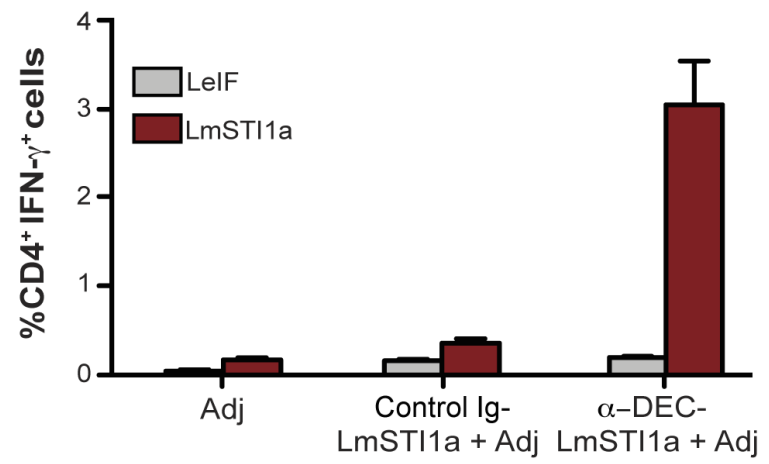

D

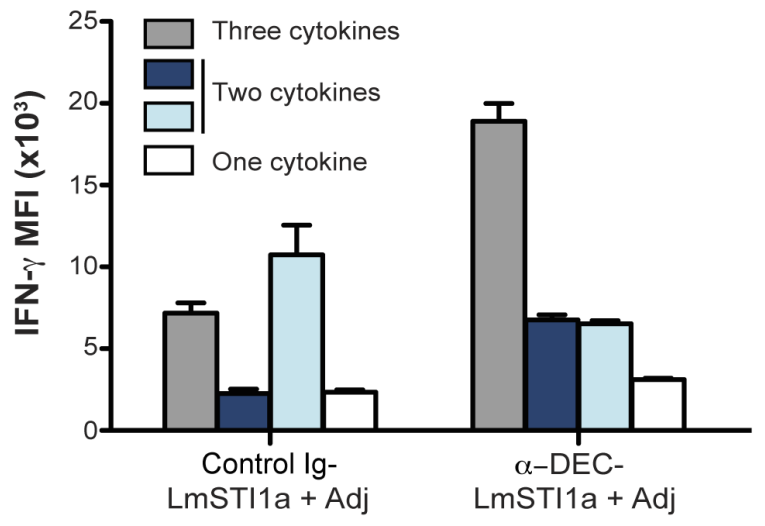

$\mathrm{IFN}-\gamma+++++++$

$\mathrm{IL}-2++\quad+\quad+\quad+-$

TNF- $\alpha+-\quad+\quad+\quad+\quad+\quad-$

$\mathbf{F}$

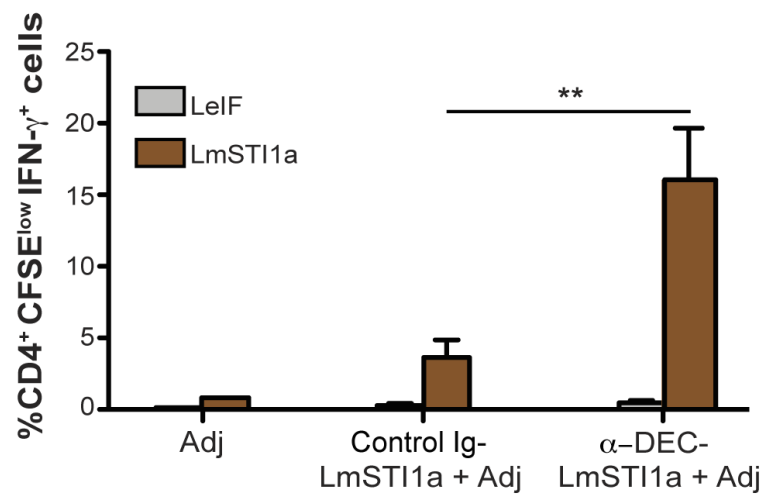

Figure 1. Single dose of anti-DEC-LmSTI1 a immunizes multifunctional Th1 CD4 ${ }^{+} \mathbf{T}$ cells in vivo. (A) C57BL/6 mice were intraperitoneally inoculated with $1 \mu \mathrm{g}$ of anti-DEC-LmSTI1a or control Ig-LmSTI1a plus $50 \mu \mathrm{g}$ poly ICLC and $25 \mu \mathrm{g}$ anti-CD40 mAb (Adjuvants, Adj). Fourteen days later, splenocytes were restimulated in vitro with LmSTI1a reactive peptide mix or LelF nonreactive peptide mix in the presence of BFA. Intracellular cytokine staining was performed to detect IFN- $\gamma$ in $\mathrm{CD}^{+} \mathrm{CD}^{+}$T cells. (B) As in A, but $\%$ of IFN- $\gamma^{+} \mathrm{CD} 4^{+} \mathrm{T}$ cells is shown as mean $\pm \mathrm{SEM}(\mathrm{n}=9$ ). (C) Top panel shows the gating strategy to identify multifunctional T cells using multiparameter flow cytometry. $\mathrm{CD}^{+}{ }^{+} \mathrm{CD} 4^{+}$IFN- $\gamma^{+} \mathrm{T}$ cells (middle FACS plot) were analyzed for production of IL-2 and TNF- $\alpha$ (right FACS plot). Bottom bar graph shows the frequencies of total CD4 ${ }^{+}$T cells expressing each of the four cytokine combinations. Graph is expressed as the frequency of $C D 4^{+} \mathrm{CD}^{+}$T cells and the mean \pm SEM $(n=9)$. (D) IFN- $\gamma$ median fluorescence intensity (MFI) of antigen-specific CD4 ${ }^{+}$T cells producing three, two, or one cytokines (IFN- $\gamma$ alone or with TNF- $\alpha$ and/or IL-2) following immunization of C57BL/6 mice as in A. (E) As in A, but in Balb/c mice. The \% of CD4 $4^{+}$cells is shown as the mean \pm SEM $(n=10)$. (F) As in $E$, but bulk splenocytes were CFSE-labeled and stimulated with LmSTI1a reactive peptide mix or LelF nonreactive peptide mix for 4 days, wherein the cells were restimulated with $\mathrm{LmSTI1}$ a reactive peptide mix in the presence of BFA to detect IFN- $\gamma^{+}$cells in proliferating CFSE ${ }^{\text {low }} \mathrm{CD}^{+} \mathrm{CD}^{+} \mathrm{T}$ cells. The frequency of CFSE ${ }^{\text {low }}$ IFN $-\gamma^{+} \mathrm{CD}^{+} T$ cells is shown as the mean \pm SEM $(n=6)$.

doi:10.1371/journal.pone.0067453.g001 
Targeting LmSTI1a to DCs via anti-DEC mAb is more Efficient than Non-targeted LmSTI1a Protein for Induction of Th1 $\mathrm{CD}^{+} \mathrm{T}$ cell Responses

To evaluate the role of DGs in immunization, C57BL/6 mice were inoculated with graded doses of anti-DEC-LmSTIla mAbs, control Ig-LmSTIla mAb, or non-targeted LmSTIla protein in the presence of the adjuvant. Anti-DEG-LmSTIla was more efficient than control Ig-LmSTIla at priming IFN- $\gamma$-producing $\mathrm{CD}^{+} \mathrm{T}$ cells and elicited significantly greater $\mathrm{T}$ cell responses than equivalent amounts of non-targeted protein (Figure 2A).

We further confirmed that these responses were receptor mediated. As shown in Figure 2B, T cell responses induced by anti-DEC-LmSTIla in DEG-deficient mice were reduced approximately 10-fold (Figure 2B). Thus, DEC-mediated delivery of LmSTIla antigen to DCs in vivo results in antigen-specific CD $4^{+} \mathrm{T}$ cell responses that are dependent on the presence of the DEC receptor.

\section{$\mathrm{CD}^{+} \mathrm{T}$ cell Responses Induced by anti-DEC-LmSTI1a are Directed to Several LmSTI1a Epitopes}

The breadth of antigen-specific $\mathrm{T}$ cell responses is reflected by the diversity of reactive epitopes recognized by $\mathrm{T}$ cells on distinct MHC class II haplotypes. To assess the breadth of the Th1 response and identify the individual LmSTIla epitopes recognized by antigen-specific $\mathrm{CD} 4^{+} \mathrm{T}$ cells following immunization with anti-DEC-LmSTIla mAb, we used a peptide library of 15-mer "mimetopes" staggered by 4aa along the 1-398 aa sequence of LmSTIla. The library was divided into 10 sequential peptide pools, each containing 12 peptides. Each pool was used to restimulate splenocytes from mice immunized with anti-DECLmSTIla mAb, and IFN- $\gamma$ production was evaluated by FACS. As shown in Figure 3, CD $4^{+} \mathrm{T}$ cells from Balb/c and C57BL/6 mice responded to at least two different peptide pools, pool 2 and 8, whereas C57BL/6 mice also responded to peptide(s) in pool 1 (Figure 3, A and B). The aa sequences covered by LmSTIla peptide pools 1, 2, and 8 are shown in Table S1.
We then identified individual reactive peptides in the $\mathrm{H}-2^{\mathrm{d}}$ haplotype. Each peptide within pools 2 and 8 was used to restimulate splenocytes from Balb/c mice immunized with antiDEG-LmSTIla (Figure S4A). We found that the $\mathrm{CD}^{+} \mathrm{T}$ cell responses in Balb/c mice were directed to two overlapping peptides from each pool, i.e., peptides 16-17 in pool 2 and 87-88 in pool 8 (Figure S4A and Table 1). The sequences within these peptides cover two epitopes previously described in the $\mathrm{H}-2^{\mathrm{d}}$ haplotype (Figure S4A, underlined aa sequences) [37]).

To identify individual reactive CD4 epitopes in the $\mathrm{H}-2^{\mathrm{b}}$ haplotype, which have not been reported previously, C57BL/6 splenocytes of mice immunized with anti-DEC-LmSTIla were restimulated with single peptides from pools 1, 2, and 8 (Figure $\mathrm{S} 4 \mathrm{~B}$ ). Six peptides (two overlapping peptides from each pool) were able to induce IFN- $\gamma$ production by $\mathrm{CD} 4^{+} \mathrm{T}$ cells from anti-DECLmSTIla immunized mice (Figure S4B and Table 1). The dominant epitope was located within aa 348-366 (VEEAYIDPEIAKQKKDEGN) of the LmSTI1 sequence (Table 1).

Since the $\mathrm{CD}^{+} \mathrm{T}$ cell responses were mainly directed to three immunodominant overlapping peptides localized in pool 8, peptides 87,88 , and 89 , we genetically engineered their peptide sequence into the C-terminal domain of the heavy chain of antiDEC mAb (anti-DEC-LmsTI1 ${ }_{344-366}$; Figure S2). Balb/c mice were immunized with anti-DEC-LmsTI $1_{344^{-}-366}$ plus adjuvant, and 14 days later, we evaluated IFN- $\gamma$-producing $\mathrm{CD} 4^{+} \mathrm{T}$ cells by FACS. Inoculation of $1 \mu \mathrm{g}$ of anti-DEC-LmSTI $1_{344-366} \mathrm{mAb}$ generated around two times more IFN- $\gamma$-producing $\mathrm{CD} 4^{+} \mathrm{T}$ cells than $10 \mu \mathrm{g}$ of non-targeted $\mathrm{LmSTI}_{344-366}$ peptide, suggesting that peptide targeting to DCs was approximately 20 times more efficient (Figure 3C). The frequency of $\mathrm{CD}^{+} \mathrm{T}$ cells producing IFN- $\gamma$ after immunization with anti-DEC-LmSTI $1_{344-366}$ was slightly lower than, but not significantly different from, animals immunized with anti-DEC-LmSTIla mAbs (Figure 3C).

Thus, a single inoculation of LmSTIla targeted to DCs using anti-DEC mAb results in broad $\mathrm{CD} 4^{+} \mathrm{T}$ cell responses directed to at least two different peptides in $\mathrm{H}-2^{\mathrm{d}}$ and $\mathrm{H}-2^{\mathrm{b}}$ backgrounds, including a dominant epitope localized within aa $344-366$. In
A

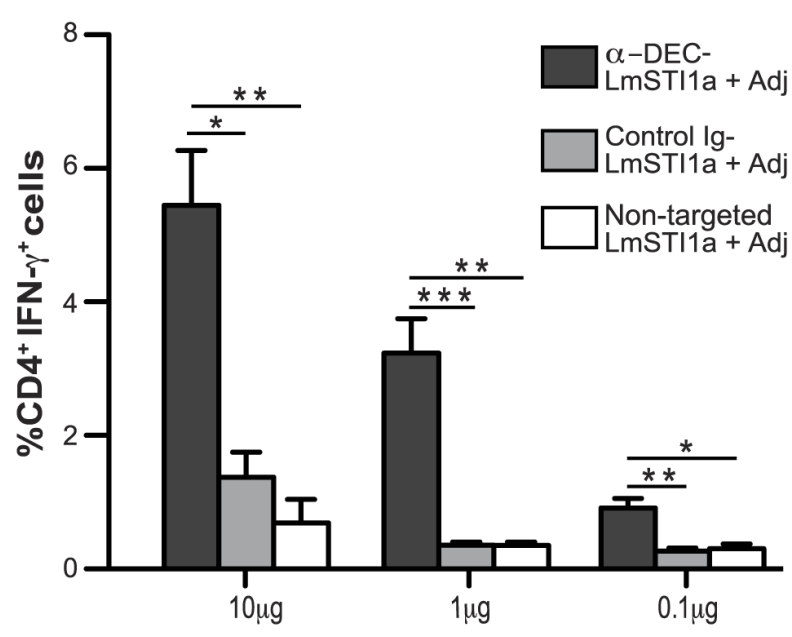

B

C57BL/6 Wild Type
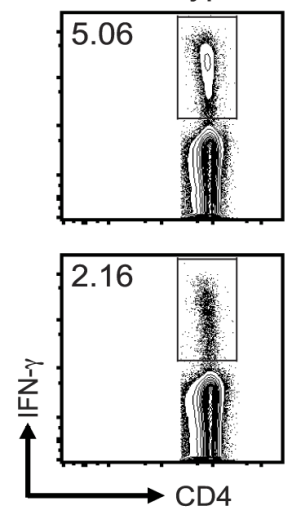

C57BL/6
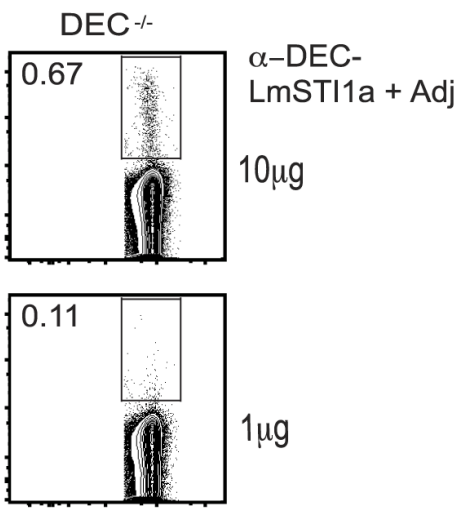

Figure 2. Priming of Th1 $\mathrm{CD}^{+} \mathbf{T}$ cells with anti-DEC-LmSTI1a in vivo requires targeting to $\mathrm{DEC}^{+} \mathrm{DCs}$. (A) C57BL/6 mice were intraperitoneally immunized with different doses of anti-DEC-LmSTI1a, control Ig-LmSTI1a, or non-targeted LmSTI1a protein (0.1-10 $\mu \mathrm{g})$ in the presence of $50 \mu \mathrm{g}$ poly ICLC and $25 \mu \mathrm{g}$ anti-CD40 (Adj). Fourteen days after immunization, splenocytes were restimulated in vitro with a reactive LmSTI1 a peptide mix for $6 \mathrm{~h}$ in the presence of BFA. Intracellular staining was performed to detect IFN- $\gamma$ production in $\mathrm{CD} 3^{+} \mathrm{CD} 4^{+} \mathrm{T}$ cells. The mean \pm SEM $(n=6)$. (B) As in A, but C57BL/6 wild-type or $\mathrm{DEC}^{-1-}$ mice were immunized with 10 or $1 \mu \mathrm{g}$ of anti-DEC-LmSTI1a mAb plus Adj. Plots are representative of two experiments.

doi:10.1371/journal.pone.0067453.g002 
A

LmSTI1a

\begin{tabular}{|c|c|c|c|c|c|c|c|c|c|c|c|}
\hline & LelF & Pool 1 & Pool 2 & Pool 3 & Pool 4 & Pool 5 & Pool 6 & Pool 7 & Pool 8 & Pool 9 & Pool 10 \\
\hline Balb/c & 0.09 & $\overline{0.09}$ & $\overline{\overline{c 0.34}}$ & 0,1 & 0.07 & 0.05 & 0.06 & $\overline{0.06}$ & $\overline{1.09}$ & 0.07 & $\longdiv { 0 . 0 9 }$ \\
\hline
\end{tabular}

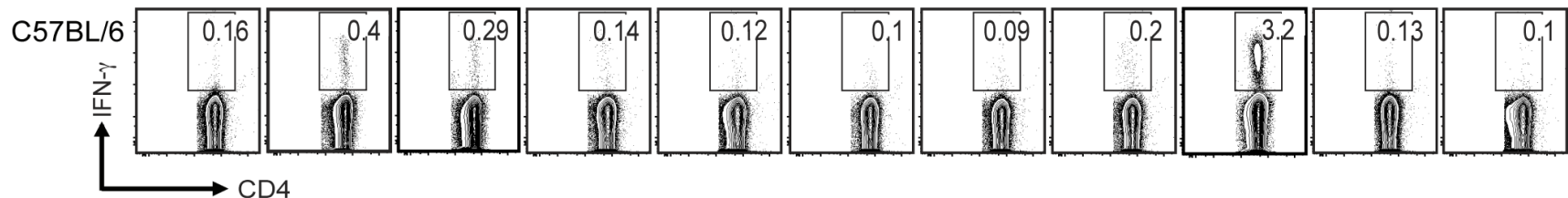

B

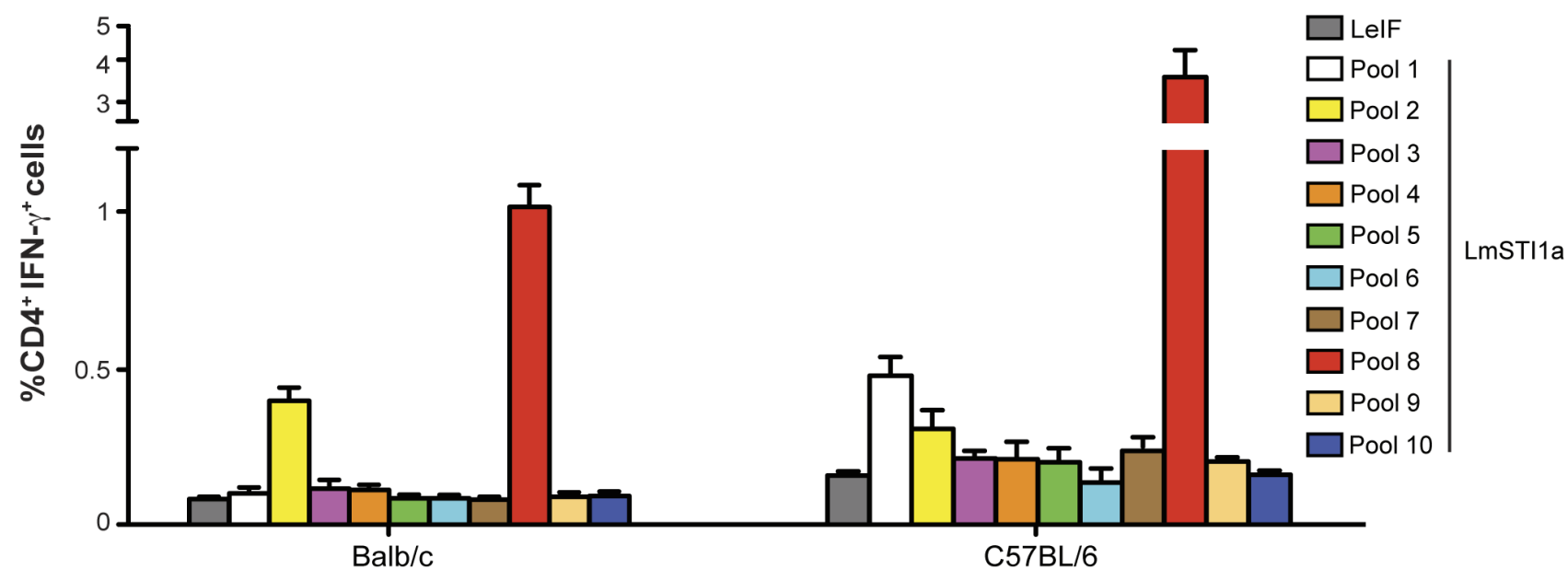

C

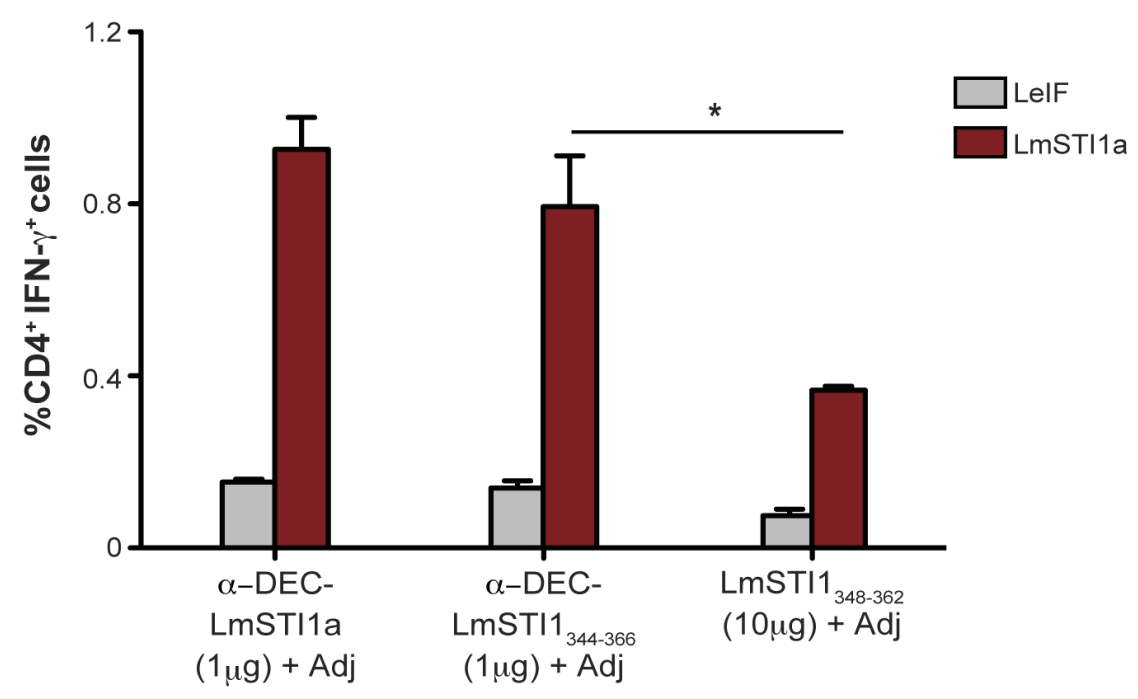

Figure 3. CD4 ${ }^{+} \mathbf{T}$ cell responses induced by anti-DEC-LmSTI1a are directed to several epitopes. (A) Balb/c or C57BL/6 mice were intraperitoneally immunized with $1 \mu \mathrm{g}$ of anti-DEC-LmSTI1a plus poly ICLC (50 $\mu \mathrm{g})$ and anti-CD40 mAb (25 $\mu \mathrm{g})$ (Adj). Fourteen days later, splenocytes were restimulated with 10 different $\mathrm{LmSTI} 1$ a peptide pools $(2 \mu \mathrm{g} / \mathrm{ml})$, each containing 12 individual peptides. IFN- $\gamma$-producing CD4 ${ }^{+} \mathrm{T}_{\text {cells }}$ were assessed by intracellular cytokine staining. (B) As in A, but the percentage of IFN- $\gamma^{+} C D 4^{+}$T cells is shown as mean \pm SEM ( $\left.n=6\right)$. (C) Balb/c mice were immunized with $1 \mu \mathrm{g}$ of anti-DEC-LmSTI1 a or anti-DEC-LmSTI1 ${ }_{344-366}$ mAbs or $10 \mu \mathrm{g}$ of non-targeted LmSTI $_{348-362}$ immunodominant peptide in the presence of $50 \mu \mathrm{g}$ poly ICLC and $25 \mu \mathrm{g}$ anti-CD40 mAb (Adj). Production of IFN- $\gamma$ was evaluated by FACS after restimulation with LmSTI1a reactive peptide mix or LelF nonreactive peptide mix. The $\%$ of IFN $-\gamma^{+} \mathrm{CD}^{+}$T cells is shown as mean \pm SEM $(n=3)$.

doi:10.1371/journal.pone.0067453.g003 
Table 1. Identification of putative LmSTI1a-specific MHC II restricted peptides.

\begin{tabular}{|c|c|c|c|c|c|c|}
\hline Strain & $\begin{array}{l}\text { MHC II } \\
\text { haplotype }\end{array}$ & $\begin{array}{l}\text { LmSTI } \\
\text { peptide pool }\end{array}$ & $\begin{array}{l}\text { Responding } \\
\text { 15-mer peptide }\end{array}$ & Position (aa) & Sequence & $\%$ IFN- $\gamma^{+} \mathrm{CD4}^{+} \mathrm{T}$ cells \\
\hline \multirow[t]{2}{*}{ C57BI/6 } & $\mathrm{H}-2^{\mathrm{b}}$ & 1 & p5 & $17-31$ & GRYVEAVNYFSKAIQ & $0.526 \pm 0.159$ \\
\hline & & & p6 & $21-35$ & EAVNYFSKAIQLDEQ & $0.266 \pm 0.120$ \\
\hline \multirow[t]{2}{*}{$\mathrm{C} 57 \mathrm{BI} / 6$} & $\mathrm{H}-2^{\mathrm{b}}$ & 2 & p16 & $61-75$ & DKCISIKPNWAKGYV & $0.315 \pm 0.198$ \\
\hline & & & p17 & $65-79$ & SIKPNWAKGYVRRGA & $0.236 \pm 0.146$ \\
\hline \multirow[t]{2}{*}{ C57BI/6 } & $\mathrm{H}-2^{\mathrm{b}}$ & 8 & $\mathrm{p} 88$ & $348-362$ & VEEAYIDPEIAKQKK & $3.052 \pm 0.982$ \\
\hline & & & p89 & $352-366$ & YIDPEIAKQKKDEGN & $2.335 \pm 0.776$ \\
\hline \multirow[t]{2}{*}{ Balb/c } & $H-2^{d}$ & 2 & p16 & $61-75$ & DKCISIKPNWAKGYV & $0.390 \pm 0.103$ \\
\hline & & & p17 & $65-79$ & SIKPNWAKGYVRRGA & $0.215 \pm 0.035$ \\
\hline \multirow[t]{2}{*}{ Balb/c } & $H-2^{d}$ & 8 & p87 & $344-358$ & HQKAVEEAYIDPEIA & $0.805 \pm 0.173$ \\
\hline & & & p88 & $348-362$ & VEEAYIDPEIAKQKK & $1.012 \pm 0.366$ \\
\hline
\end{tabular}

doi:10.1371/journal.pone.0067453.t001

addition, when the immunodominant $\mathrm{LmSTI}_{344-366}$ peptide is delivered using anti-DEC mAb, the efficiency of targeting is preserved.

\section{LmSTI1 is a Superior Antigen for Induction of Th1 Responses}

Identification of protective antigens is a major goal for generation of new and improved vaccines against $L$. major. Accordingly, we compared LmSTIla with other previously described antigens of Leishmania spp., LACK and LeIF, for their capacity to induce IFN- $\gamma$-producing $\mathrm{CD} 4^{+} \mathrm{T}$ cells and protect against subsequent challenge with $L$. major.

Since the immunomodulatory properties of LeIF are localized in the N-terminal domain (aa 1-226) [38], we genetically

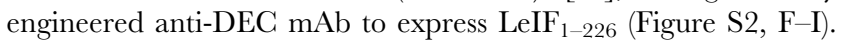
We also used for comparison anti-DEC-LACK mAb [20], and the C-terminus domain of the LmSTIl gene (anti-DEC-LmSTIlb, Figure S2, A-E).

$\mathrm{Balb} / \mathrm{c}$ mice were immunized with anti-DEC mAb coupled with LmSTIla, LmSTIlb, LACK, or LeIF along with the adjuvant, and antigen-specific responses were evaluated by detection of IFN$\gamma$-producing $\mathrm{CD}^{+} \mathrm{T}$ cells. As shown in Figure 4, anti-DECLmSTIla and anti-DEC-LmSTI1b induced the highest frequencies of IFN- $\gamma^{+} \mathrm{CD} 4^{+} \mathrm{T}$ cells compared with anti-DEC-LACK or LeIF. Epitope analysis revealed that the response to LACK was directed to a single, previously described epitope, corresponding to aa 156-173 (Table 2) [39]. The CD4 ${ }^{+} \mathrm{T}$ cell response to LeIF in Balb/c mice was also directed to a single, uncharacterized epitope localized in our pool 5 within aa 141-162 (Figure S4C and Table 2).

In contrast to targeting LACK or LeIF, delivery of LmSTIlb using anti-DEC mAb induced higher frequencies of $\mathrm{CD}^{+} \mathrm{IFN}^{-}{ }^{+}$ $\mathrm{T}$ cells than delivery of LmSTIla (Figure 4). However, LmSTIlbspecific $\mathrm{CD} 4^{+} \mathrm{T}$ cell responses were directed to a single, previously described epitope [37] localized in our pools 9-10 (Figure S4D), within aa 422-444 (Table 2). Moreover, LmsTIlb, as well as LACK and LeIF, induced $\mathrm{CD} 4^{+} \mathrm{T}$ cell responses only in Balb/c mice and not in C57BL/6 mice (data not shown). Overall, we concluded that LmSTIla has several advantages compared with other L. major antigens, including potent generation of Th1 T cell responses directed to at least two epitopes in two different haplotypes, i.e., $\mathrm{H}-2^{\mathrm{b}}$ and $\mathrm{H}-2^{\mathrm{d}}$.
Targeting LmSTI1a to DCs Using mAbs against DEC Elicits Superior Protection against $L$. major Challenge

We next compared the protective potential of different Leishmania antigens delivered to DCs within mAb against DEC. To facilitate translation into the clinic, we inoculated fusion $\mathrm{mAbs}$ subcutaneously, which is one of the most attractive ways for vaccination in humans $[40,41]$, in a prime-boost regimen using poly ICLC as the adjuvant $[24,25]$.

Susceptible Balb/c mice vaccinated with different antigens fused to anti-DEC mAbs were challenged 10-15 days later with a low dose of metacyclic promastigotes administered intradermally in the ear pinnae. Lesion development and parasite burden was evaluated in the challenged site and ear-draining lymph nodes (LNs). Vaccination with anti-DEG-LmSTIl a mAb plus poly ICLC resulted in approximately $100 \%$ protection (16 mice in four independent experiments), i.e., reduced pinnae edema and necrosis. In contrast, anti-DEC-LeIF mAb resulted in approximately $30-40 \%$ protection (six of 16 mice in four different experiments), while anti-DEC-LACK failed to induce protection against $L$. major infection (Figure S5A). Skin lesions were correlated with parasite numbers in the ear and ear-infected draining LNs (Figure 5, A and B). Mice vaccinated with anti-DEC-LmSTIla $\mathrm{mAb}$ showed significantly lower number of parasites at the earinfected draining LN (Figure 5A) compared with control-Ig LmSTIa and almost no parasites in the ear pinnae (Figure 5B). Vaccination with anti-DEG-LeIF $\mathrm{mAb}$ also exhibited moderate reduction in the size of the lesions, which correlated with a lower number of parasites in the LN and ear pinnea than that in PBStreated animals, but was not as potent as treatment with antiDEC-LmSTIla (Figure 5, A and B). On the other hand, mice treated with anti-DEC-LACK or control Ig-LmSTIa mAbs showed the highest number of parasites in the infection site and the ear-infected draining LN (Figure 5, A and B).

The protective effect of anti-DEC-LmSTIla mAb was also observed when Balb/c mice were challenged with a high dose of metacyclic promastigotes administered subcutaneously in the footpad (Figure S5B). Again, anti-DEC-LmSTIla mAbs conferred complete protection (100\% of the animals) with negligible footpad swelling and undetectable parasites in the lesions, whereas antiDEC-LeIF and anti-DEC-LmSTI1b resulted in partial protection (40\% and $80 \%$ of the animals, respectively; Figure S5B and C).

We further evaluated the protective effect of anti-DECLmSTIla in the innately resistant mouse strain C57BL/6. As shown in Figure S5D, vaccination of C57BL/6 mice with anti- 


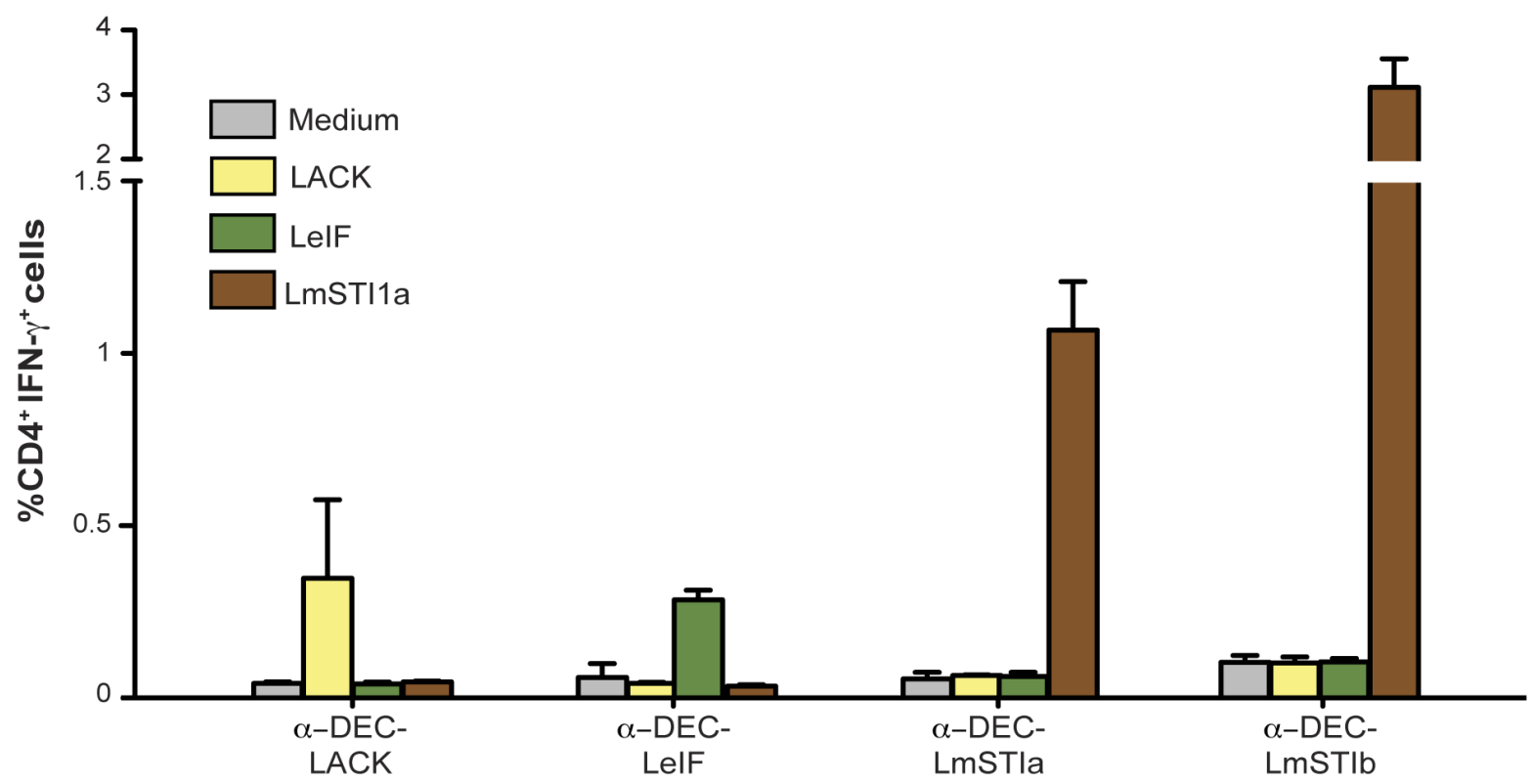

Figure 4. LmSTI1 targeted within anti-DEC mAbs induces superior Th1 immunity compared with other L. major antigens. Balb/c mice were intraperitoneally immunized with $10 \mu \mathrm{g}$ of anti-DEC mAbs fused with LACK, LeIF, LmSTI1a, or LmSTI1b in the presence of $50 \mu \mathrm{g}$ poly ICLC and $25 \mu \mathrm{g}$ anti-CD40 mAb (Adj). Fourteen days after the immunization, splenocytes were restimulated in vitro with $2 \mu \mathrm{g}$ of LACK, LeIF, or LmSTI1 peptide mix or medium alone (negative control) in the presence of BFA for $6 \mathrm{~h}$. Intracellular cytokine staining was performed to detect IFN- $\gamma^{+}$cells on CD3 ${ }^{+}$ $\mathrm{CD4}^{+} \mathrm{T}$ cells. Data is shown as the mean \pm SEM $(n=4-8)$.

doi:10.1371/journal.pone.0067453.g004

DEC-LmSTIla mAb plus poly ICLC could confer some degree of protection against a low dose of metacyclic promastigotes administered intradermally represented by the reduced number of parasites detected in the infection site.

Finally, we evaluated the ability of anti-DEC-LmSTIla to confer long-term protection against infection. Balb/c mice immunized with anti-DEC-LmSTIla mAb plus adjuvant were challenged with live metacyclic promastigotes 12 weeks after the last immunization. Only immunization with anti-DEC-LmSTIla, but not a control Ig-LmSTIla mAb, could confer durable protection $(100 \%$ of the animals), which correlated with a low number of parasites in the ears and ear-infected draining LN (Figure 5C, data now shown).

To examine the nature of the protection induced by anti-DECLmSTIla mAb, we analyzed IFN- $\gamma$, IL-4, and IL-10 responses 12 weeks after challenge with $L$. major. Lymphocytes from ear-infected draining LN from mice immunized with anti-DEC-LmSTIla produced significantly less IL-4 in response to stimulation ex vivo with soluble Leishmania antigen (SLA) but comparable levels of IFN- $\gamma$ compared with mice inoculated with control Ig-LmSTI1 (Figure S6, A and B). Consequently, the IFN- $\gamma / \mathrm{IL}-4$ ratios in mice vaccinated with anti-DEC-LmSTIla were highest compared with control Ig-LmSTI1, anti-DEC-LeIF, or anti-DEC-LACK (Figure 6A). Similarly, lymphocytes from mice vaccinated with anti-DEC-LmSTIla produced significantly less IL-10 after stimulation ex vivo with SLA (Figure 6B). Taken together, these results suggest that the superior protection in anti-DEC-LmSTIla vaccinated mice can be explained, at least in part, by a shift toward a Thl phenotype.

Overall, we concluded that LmSTI1 targeted to DCs via DEG mAbs is the most effective L. major antigen to prevent cutaneous leishmaniasis.

\section{Discussion}

Given the lack of effective and low-cost treatment, several strategies are being evaluated as potential vaccine candidates against leishmaniasis $[7,8,9,10,11]$; however, there are still no licensed vaccines [42]. Considering their unique capacity to induce and regulate immune responses, DCs offer a promising approach for development of novel vaccines. It has been previously shown that adoptive transfer of DCs loaded ex vivo with parasite antigens can mediate protection against Leishmania infection [7,19,43]. However, this approach relies on laborious and expensive isolation

Table 2. Identification of LACK-, LelF-, and LmSTI1b-specific CD4 ${ }^{+} \mathrm{T}$ cell responding peptides in Balb/c mice.

\begin{tabular}{lllll}
\hline & & & \\
\hline L. major antigen & Reactive peptide pool & Responding 15-mer peptide & Position (aa) & Sequence \\
\hline LACK & 1 & $\mathrm{p} 7-\mathrm{p} 8$ & $156-173$ & ICFSPSLEHPIVVSGSWD' $^{1}$ \\
LelF & 5 & $\mathrm{p} 43-\mathrm{p} 45$ & $141-162$ & LRKLQAGVIVAVGTPGRVSDVI \\
LmSTI1b & $9-10$ & $\mathrm{p} 107-\mathrm{p} 109$ & $422-444$ & KPDFVKGYARKGHAYFWTKQYNR $^{2}$ \\
\hline
\end{tabular}

${ }^{1}$ The sequence of the previously described reactive epitope in Balb/c mice is underlined [39].

${ }^{2}$ The sequence of the previously described reactive epitope in Balb/c mice is underlined [37].

doi:10.1371/journal.pone.0067453.t002 
A

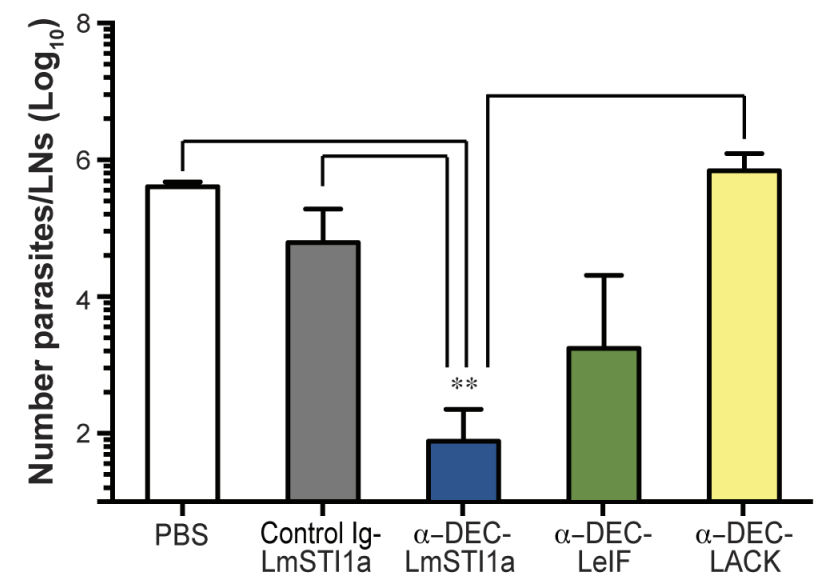

B

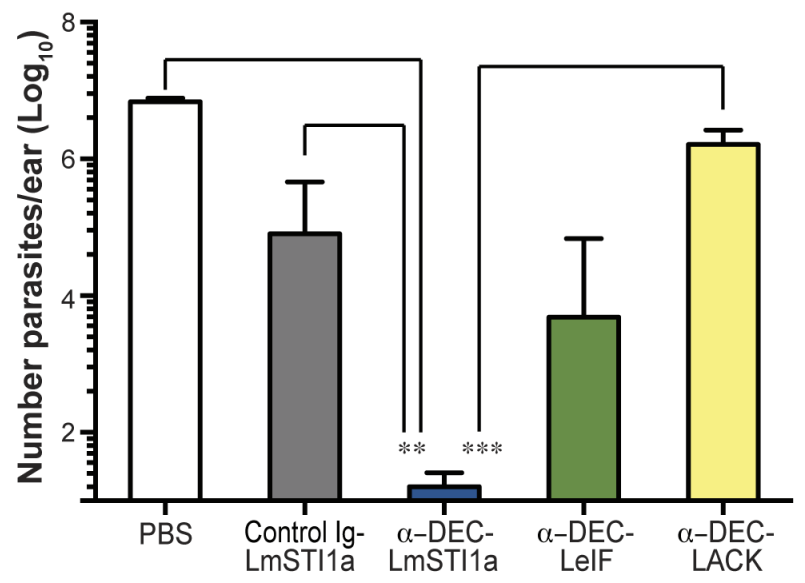

C

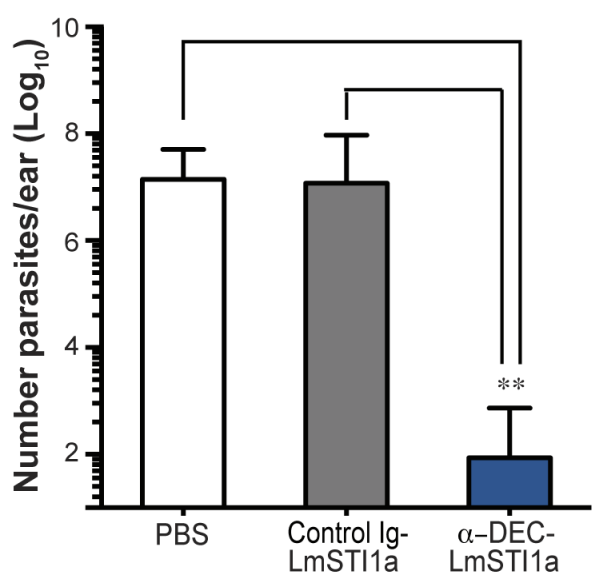

Figure 5. Anti-DEC-LmSTI1 a mAb elicits protection against $L$. major. Balb/c mice were vaccinated in a prime-boost regimen consisting of two subcutaneous doses, administered 1 month apart, with $10 \mu \mathrm{g}$ or $1 \mu \mathrm{g}$ of control Ig-LmSTI1a or anti-DEC-LmSTI1a and $10 \mu \mathrm{g}$ of anti-DEC-LACK or antiDEC-LelF mAbs in the presence of $50 \mu \mathrm{g}$ poly ICLC. Ten to 15 days after boost, the mice were intradermally injected in the ear pinnae with 200-1000 L. major metacyclic promastigotes. Quantification of parasites obtained from ear-infected draining LN (A) or per infected ears (B) were calculated 12 weeks after challenge. Shown is the mean \pm SEM $(n=5-12$, except PBS, $n=2)$. (C) As in B, but Balb/c mice were intradermally challenged with 2001000 L. major metacyclic promastigotes 12 weeks after the last immunization. Shown is the mean \pm SEM $(n=5$, except PBS, $n=3)$. doi:10.1371/journal.pone.0067453.g005

and ex vivo culture of cells. A novel approach is targeting antigens to DCs in situ in the intact animal using mAbs against DEC. Despite previous success using this DC-targeting approach for induction of protective immune responses against viruses [22], bacteria [27,28], and even tumor cells [44,45], to the best of our knowledge, this is the first report evaluating the efficacy of this strategy for generation of protective immune responses against a protozoan parasite. The findings in this report show that delivery of LmSTIl to adjuvant-matured DCs was sufficient to induce protective immunity to $L$. major, one of the causative agents of human cutaneous leishmaniasis.

We chose LmSTI1 based on several criteria. STI1 is a protein highly conserved among different Leishmania species, suggesting that in addition to being useful for L. major infection, an anti-DECLmSTIla vaccine may be useful for other forms of leishmaniasis, including visceral and mucosal leishmaniasis. LmSTIl is present in the amastigote and promastigote form of the parasite [29]. Furthermore, LmSTI1 is divergent from its mammalian protein counterpart, indicating a decreased risk for undesirable pathological crossactivation of autoreactive $\mathrm{T}$ and $\mathrm{B}$ cells. Importantly, immunization with recombinant LmSTI1 protein administered alone or as a poly protein fused with other parasite proteins induces protection in susceptible Balb/c mice [32,33,46]. Our results demonstrate that anti-DEG-LmSTIla induces several fold greater responses than LmSTIl protein alone and confers a high level of protection against challenge with $L$. major in susceptible Balb/c and resistant C57BL/6 mice. Protection against L. major infection was consistent, even at low doses $(1 \mu \mathrm{g})$ of fusion mAbs, and was durable for at least 12 weeks after immunization. In addition, anti-DEC-LmSTIla protection was achieved despite increasing the parasite load $\left(200-1 \times 10^{6}\right)$, or varying the site of infection (intradermal and subcutaneous).

Protection against Leishmania in experimental mouse models is thought to be primarily mediated by the production of IFN- $\gamma$ [3]. The main source of IFN- $\gamma$ is antigen-specific CD $4^{+}$T cells [47]. Furthermore, it was recently shown that vaccine-induced protection against $L$. major strongly correlates with generation of multifunctional Thl $\mathrm{CD}^{+}{ }^{+} \mathrm{T}$ cells producing high levels of IFN$\gamma$, IL-2, and TNF- $\alpha$ [35]. Therefore, protection against infection seems to be dependent not only on the magnitude but also on the 
A

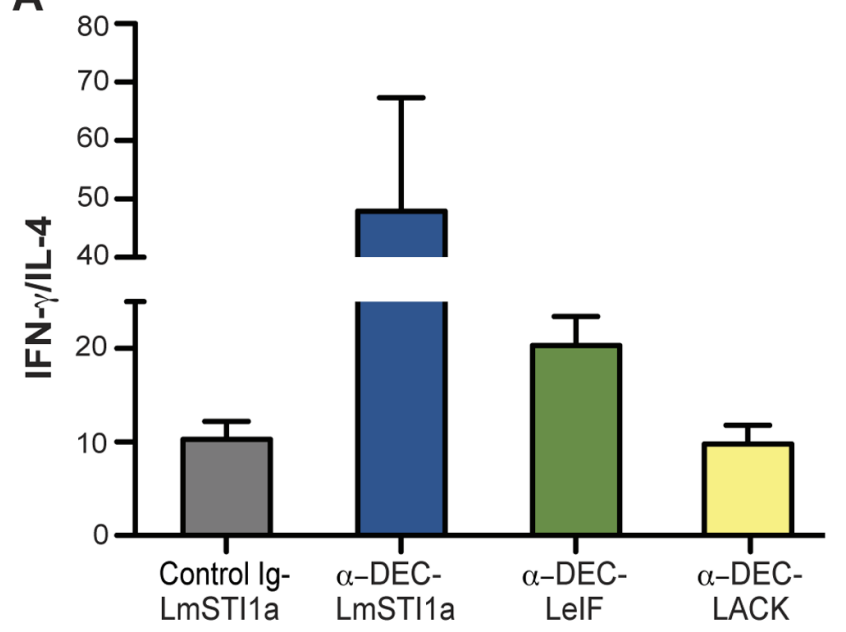

B

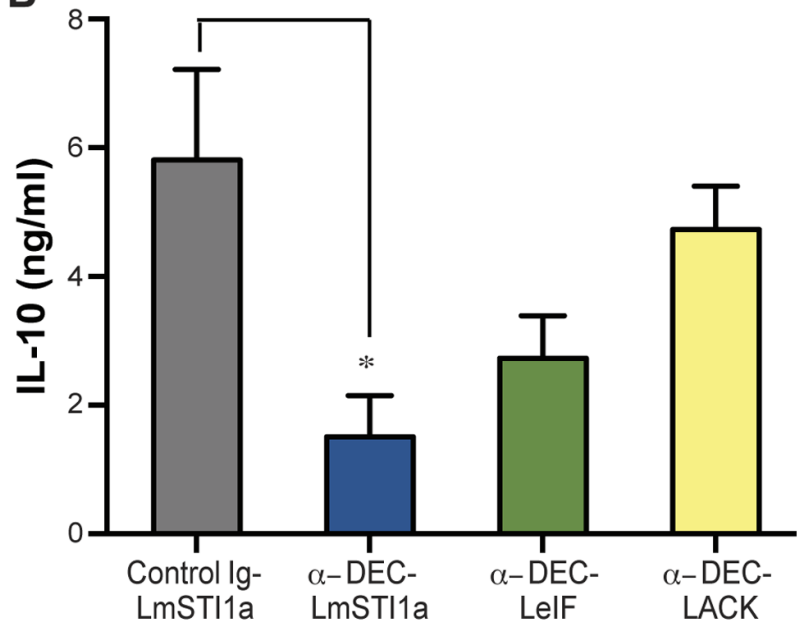

Figure 6. Analysis of the cytokine responses after challenge with $L$. major. As in Figure 5 , but 12 weeks after infection with $L$. major, total cell suspensions of ear-infected draining LN were restimulated in vitro for $72 \mathrm{~h}$ with $10 \mu \mathrm{g} / \mathrm{ml}$ of SLA. The levels of IFN- $\gamma$, IL-4, and IL-10 cytokines in the culture supernatants were determined by ELISA. Data is shown as the mean \pm SEM of the ratio of $(A)$ IFN- $\gamma / I L-4$ and $(B)$ IL-10 $(n=4-10)$. doi:10.1371/journal.pone.0067453.g006

quality of the $\mathrm{CD}^{+} \mathrm{T}$ cell response generated. Accordingly, delivery of LmSTIla to DCs via DEC mAbs in combination with a DC maturation stimulus induced potent multifunctional (IFN$\left.\gamma^{+} / \mathrm{IL}-2^{+} / \mathrm{TNF}-\alpha^{+}\right)$antigen-specific $\mathrm{CD} 4^{+} \mathrm{T}$ cells. Additionally, vaccine-induced LmSTIla-specific $\mathrm{CD}^{+} \mathrm{T}$ cells proliferated vigorously and secreted high amounts of IFN- $\gamma$ upon antigen restimulation in vitro.

The quality of the $\mathrm{CD} 4^{+} \mathrm{T}$ cell response induced by anti-DECLmSTIla mAbs was also reflected by its breadth, i.e., $\mathrm{T}$ cell responses were produced in two different $\mathrm{MHC}$ haplotypes $\left(\mathrm{H}-2^{\mathrm{b}}\right.$ and $\mathrm{H}-2^{\mathrm{d}}$ ), and the response was directed to at least two peptides in each haplotype. The peptides recognized following anti-DECLmSTIla immunization in Balb/c mice were identical to those reported previously in $\mathrm{H}-2^{\mathrm{d}}$ [37]. We extended the analysis to identify peptides recognized by $\mathrm{CD} 4^{+} \mathrm{T}$ cells in $\mathrm{C} 57 \mathrm{BL} / 6\left(\mathrm{H}-2^{\mathrm{b}}\right)$, which had not been assessed previously. Interestingly, the $\mathrm{CD} 4^{+} \mathrm{T}$ cell response was mainly directed to a dominant peptide, similar in sequence to the one recognized in Balb/c mice. Consequently, we delivered the $\mathrm{LmSTI}_{344-366}$ peptide to DCs using anti-DEC $\mathrm{mAbs}$, and as expected, this strategy also immunizes $\mathrm{CD} 4^{+} \mathrm{T}$ cells.

We further compared other $L$. major proteins as vaccine candidates by DEG targeting to DCs. LACK is another wellconserved Leishmania antigen; however, previous reports indicate that LACK fails to elicit long-term protective immune responses against L. major or other Leishmania species $[48,49]$. Despite the ability of anti-DEC-LACK mAbs to prime some IFN- $\gamma^{+} \mathrm{CD} 4^{+} \mathrm{T}$ cells in agreement with a previous report [20], LACK targeting did not confer any protection against a low-dose $L$. major challenge in susceptible Balb/c mice, suggesting that this antigen is not adequate for traditional and/or DC-targeting immunization approaches.

On the other hand, LeIF antigen can expand antigen-specific Thl cells [38,50], and in our DEC DC-targeting model, it induced detectable levels of antigen-specific IFN- $\gamma$-producing $\mathrm{CD}^{+}{ }^{+} \mathrm{T}$ cells. Distinct from LmSTIla, responses induced by LeIF were restricted to $\mathrm{H}-2^{\mathrm{d}}$, as shown by the lack of $\mathrm{CD}^{+} \mathrm{T}$ cell induction in $\mathrm{C} 57 \mathrm{BL} / 6$ mice. Immunization of Balb/c mice with anti-DECLeIF induced partial protection (30-40\%) following challenge with L. major. This could be related to the fact that the $\mathrm{CD}^{+} \mathrm{T}$ cell response with anti-DEC-LeIF was directed to only one epitope and induced lower frequencies of $\mathrm{IFN}-\gamma^{+} \mathrm{CD} 4^{+} \mathrm{T}$ cells compared with LmSTIla.

Given that the entire LmSTI1 protein could not be coupled to anti-DEC mAb, we performed a partial comparison of the $\mathrm{N}$ terminal (LmSTIla) and C-terminal (LmSTIlb) portions. Compared with LmSTIla, LmSTI1b-specific $\mathrm{CD}^{+}{ }^{+} \mathrm{T}$ cell responses were restricted to $\mathrm{H}-2^{\mathrm{d}}$ and were directed to a single immunodominant epitope. Nevertheless, anti-DEC-LmSTIlb mAb induced high frequencies of IFN- $\gamma^{+} \mathrm{CD} 4^{+} \mathrm{T}$ cells and protective responses to a high-dose subcutaneous challenge with $L$. major. In the future, it will be interesting to study the effectiveness of a DCbased vaccine that includes more than one Leishmania antigen, e.g., LmSTIla, LmSTIlb, and LeIF. Such a vaccine, Leish-111f $[32,51]$, is currently being studied with protective responses; however, it would be interesting to see if its efficacy is increased by DC targeting.

Despite the antigen being targeted, we found that protection against L. major infection was associated with a significant difference in the IFN- $\gamma /$ IL-4 cytokine ratio, driven mainly by the decreased secretion of IL-4 in protected mice. Interestingly, we also found a decrease in the secretion of IL-10 in anti-DECLmSTIla vaccinated mice. These results suggest that although additional, unexplored mechanisms may be involved, a Th1biased response is correlated with protective immunity.

Efficient induction of $\mathrm{CD} 4^{+} \mathrm{T}$ cell responses in our model was dependent on the expression of the DEC receptor, as shown in DEC-deficient mice. In mice, DEC is expressed by a subset of DCs coexpressing CD8 $\alpha$ that is able to produce high levels of IL-12 in response to microbial signals $[52,53]$. This ability to produce IL-12 is critical for generation of Thl responses. Indeed, targeting CD8 $\alpha \alpha^{+}$DCs, but not CD8 $\alpha \alpha^{-}$DCs, leads to a large polarized antigen-specific Thl response [20,24]. Furthermore, skin migratory DC subsets, including Langerhans cells and dermal DCs, express high levels of DEC and may be involved in generation of protective Th1-dependent immunity via IL-12 [3]. Further studies are needed to investigate the role of distinct DCs subsets in generation of protective Thl $\mathrm{T}$ cell responses after targeting of leishmania antigens to $\mathrm{DEC}^{+}$DCs.

Priming of Thl $\mathrm{CD}^{+} \mathrm{T}$ cell responses using anti-DEC $\mathrm{mAb}$ requires maturation of DCs with TLR agonists. In this study, we 
selected poly ICLC, a microbial mimic TLR-3 and MDA5 agonist, because of its capacity to promote strong Thl responses $[24,25,26]$ and its superiority compared with other adjuvants, e.g., GLA-SE [54]. Importantly, poly ICLC is safe and well tolerated in humans [55].

Preventive vaccines are considered the best and most costeffective approaches against pathogens, including Leishmania. Here we demonstrate how DGs can be exploited to prevent infection induced by the human intracellular pathogen L. major. As we learn more about DCs, we can decide about different targeting strategies. For example, we can direct antigens to distinct subsets of DCs in vivo using mAbs against uptake receptors differentially expressed by DC populations. In this regard, it would be interesting to evaluate targeting of Leishmania antigens to CD207/Langerin ${ }^{+}$DC, including Langerhans cells, which are one of the parasite's targets [56]. Furthermore, Leishmania antigens can be delivered to macrophages, the cell type most infected by the parasite [57], using mAbs against Treml4 [45].

Taken together, our results show that delivery of LmSTIla to adjuvant-matured DCs significantly enhances antiparasite immunity. This strategy would seem logical to pursue clinically as a feasible approach for Leishmania infections.

\section{Materials and Methods}

\section{Mice}

We purchased female Balb/cJ and C57BL/6J mice from The Jackson Laboratory. $\mathrm{DEC}^{-/-}$mice were kindly provided by $\mathrm{M}$. Nussenzweig (The Rockefeller University, New York, NY) and bred in house. The mice were maintained under specific pathogen-free conditions and used at 6-8 weeks of age.

\section{Ethics Statement}

This study was conducted in accordance with the recommendations in the Guide for the Care and Use of Laboratory Animals of the National Institutes of Health. The protocol was approved by Animal Care and Use Committee at The Rockefeller University (Protocol Number: 11414). All surgery was performed under sodium pentobarbital anesthesia, and all efforts were made to minimize suffering.

\section{Reagents}

The following fluorescent conjugated mAbs were purchased from eBioscience (San Diego, CA) or BD Biosciences (Franklin Lakes, NJ): Alexa-488 anti-IL-2 (JES6-5H4), eFluor-450 or Alexa700 anti-CD3 (500A2), Alexa-700 or PE anti-CD4 (RM4-5), APC or PE-Cy7 anti-IFN- $\gamma$ (XMG1.2), and PE-Cy7 anti-TNF- $\alpha$ MP6$\mathrm{XT} 22$ ). Other reagents were live/dead fixable aqua or violet vitality dye from Life Technologies (Grand Island, NY), and CFSE (5,6-carboxyfluorescein diacetate succinimidyl ester, Life Technologies). Overlapping (staggered by four amino acids) 15-mer peptides covering the LmSTI1, LeIF, or LACK sequences were synthesized by H. Zebroski in the Proteomics Resource Center of The Rockefeller University.

\section{Engineering and Production of Fusion mAbs and LmsTI1a Soluble Protein}

Open reading frames were amplified by PCR from genomic DNA generously provided by Dr. Nicholas Glaichenhaus (Friedlin strain of $L$. major), with the sets of primers described in Table S2. DNA coding for $\mathrm{LmSTI}_{344-366}$ peptide was generated by the annealing of complementary synthetic oligonucleotides (Table S2). The PCR products were inserted in frame to the C-terminus of the heavy chain of anti-mouse-DEC (NLDC; [58,59,60]), and a control Ig mAb with no receptor affinity (GL1 17; [60]). The fusion mAbs were expressed by transient transfection using calcium phosphate in 293T cells in the presence of serum-free DMEM medium supplemented with Nutridoma SP (Roche Applied Science, Indianapolis, In). The mAbs were purified on protein $\mathrm{G}$ columns (GE Healthcare Biosciences, Pittsburg, PA) and characterized by SDS-PAGE and Western blotting using anti-mouseIgG1-HRP (Southern Biotech, Birmingham, AL). Binding of the produced $\mathrm{mAb}$ to the cognate receptor was verified by FACS on CHO cells stably transfected with mouse DEC, using PEconjugated goat anti-mouse-IgG (Jackson ImmunoResearch, West Grove, PA). For expression of soluble LmSTIla protein, the DNA encoding the first 1194 nucleotides of the LmSTIl gene was amplified by PCR using primers described in Table S2. The PCR products were digested with BamHI and NotI, gel purified, and ligated in frame into the pET28b-SMT3 vector (generous gift from Dr. E. Mossessova, Memorial Sloan-Kettering Cancer Center) [61], followed by transformation into BL21 Escherichia coli (Life Technologies). Soluble protein was purified by nickel-agarose chromatography (Qiagen, Valencia, CA), followed by removal of His 10-Smt3 with protease Ulp1, as described previously [61]. The concentration of all proteins produced, i.e., soluble protein and mAbs, was determined using the DC protein assay kit (BioRad, Hercules, CA). All proteins were examined for the presence of endotoxin using the Limulus amebocyte lysate assay, QCL-1000 (Cambrex, Walkersville, MD), and if necessary, removed using Triton-X, as described previously [62].

\section{Parasite Growth and Preparation of SLA}

L. major (Friedlin strain, generously provided by Frederick $\mathrm{S}$. Buckner, University of Washington) promastigotes were cultured at $27^{\circ} \mathrm{C}$ in M199 medium (Life Technologies) supplemented with $20 \%$ heat-inactivated FCS (Life Technologies), $0.5 \%$ penicillin/ streptomycin (Life Technologies), $0.1 \mathrm{mM}$ adenine (in $1 \mathrm{~N}$ $\mathrm{NaOH}$ ), and $5 \mu \mathrm{g} / \mathrm{ml}$ hemin (in 50\% triethanolamine) (both from Sigma) (Complete M199). In all experiments, promastigotes were used after one to three passages in vitro. Infective-stage metacyclic promastigotes were isolated from stationary cultures (4-5 days old) by negative selection of noninfective forms using peanut agglutinin (PNA, Vector Laboratories, Inc., Burlingame, CA. [63]). SLA was prepared from log-phase promastigotes (approximately $10^{8}$ parasites $/ \mathrm{ml}$ ), washed three times in PBS, and lyzed by seven cycles of freezing and thawing. Protein concentration was assessed by the BCA protein assay kit (Thermo Scientific, Rockford, Il).

Mice Immunization and in vivo Challenge with L. major

The mice were immunized intraperitoneally one time with fusion mAbs in the presence of a stimulus for DC maturation, which was $50 \mu \mathrm{g}$ poly ICLC (Oncovir, Washington, DC) together with $25 \mu \mathrm{g}$ IC10 agonistic anti-CD40 mAb (produced in house). For parasite challenge experiments, anti-CD40 was omitted and the mice were inoculated subcutaneously in the footpad $(50 \mu \mathrm{l}$ per pad) in a prime-boost regimen consisting of two doses of $1-10 \mu \mathrm{g}$ of fusion mAbs in the presence of $50 \mu \mathrm{g}$ poly ICLC administered 1 month apart. Two to twelve weeks after the last vaccination, the animals were completely anesthetized with $1-1.5 \mathrm{mg}$ Nembutal sodium (OVATION Pharmaceuticals, Inc.) and challenged with $L$. major stationary-phase metacyclic parasites. For high-dose challenge experiments, the mice were subcutaneously infected with $1 \times 10^{6}$ parasites in the contralateral footpad to the vaccination site, and disease progression was monitored by measurement of footpad swelling with a caliper. In the low-dose challenge experiments, the mice were intradermally infected with 2001000 parasites (in $20 \mu \mathrm{l}$ ) in the ear pinna. The animals were 
sacrificed when signs of footpad or ear ulceration became apparent at approximately 8-14 weeks after infection.

\section{Estimation of Parasite Loads}

The amount of viable parasites in the infected ear, footpad, and draining LN were determined by a limiting dilution assay, as described previously [64]. In brief, infected ears and footpads were collected, weighed, and homogenized individually in $5 \mathrm{ml}$ of complete M199. Single-cell suspensions were prepared from earinfected draining LN in complete M199 and adjusted to equal cell numbers and volumes. In all cases, 10-fold serial dilutions were performed, and for each dilution, 12 replicates were plated on 96well round-bottom plates, which were incubated for 10-15 days at $27^{\circ} \mathrm{C}$ in a $\mathrm{CO}_{2}$-free incubator. The number of parasites was estimated by multiplying the reciprocal of the last dilution showing at least one positive well with the initial dilution factor. Parasite loads were expressed as the number of $L$. major parasites per homogenized infected ear or footpad or per total cells in the draining LN.

\section{Intracellular Cytokine Staining and in vitro Proliferation Assay}

Spleens were force-passed through a $70-\mu \mathrm{m}$ cell strainer to obtain a homogeneous cell suspension in RPMI 1640 medium (Life Technologies) complemented with $10 \%$ FBS, $10 \mathrm{U} / \mathrm{ml}$ penicillin/streptomycin (Life Technologies), $200 \mu \mathrm{M} / \mathrm{ml}$ glutamine (Life Technologies), and $50 \mu \mathrm{M}$ 2-mercaptoethanol (SigmaAldrich, St. Louis, MO). Red blood cells were lysed by incubating with RBC lysis buffer (BioWhittaker, Walkersville, MD) for $1 \mathrm{~min}$. Bulk splenocytes were restimulated with 15-mer peptide mix from LmSTIl $(2 \mu \mathrm{g} / \mathrm{ml})$ or nonreactive LeIF $(2 \mu \mathrm{g} / \mathrm{ml})$ in the presence of $2 \mu \mathrm{g} / \mathrm{ml}$ of costimulatory anti-CD28 (clone 37.51, ATCG produced in house) for $6 \mathrm{~h}$ at $37^{\circ} \mathrm{C}$, adding $10 \mu \mathrm{g} / \mathrm{ml}$ Brefeldin A (BFA; $10 \mu \mathrm{g} / \mathrm{ml}$, Sigma-Aldrich) for the last $5 \mathrm{~h}$ of incubation in order to allow accumulation of intracellular cytokines. In some experiments, the splenocytes were labelled with CFSE to evaluate the proliferative capacity of primed $\mathrm{T}$ cells $[22,24]$. In brief, bulk splenocytes $\left(1 \times 10^{7}\right.$ cells $\left./ \mathrm{ml}\right)$ were labeled with $2.5 \mu \mathrm{M}$ CFSE at $37^{\circ} \mathrm{C}$ for $10 \mathrm{~min}$. CFSE-labeled $\mathrm{T}$ cells were then restimulated with 15 -mer peptide mix from LmSTI1 $(0.2 \mu \mathrm{g} / \mathrm{ml})$ or nonreactive LeIF $(0.2 \mu \mathrm{g} / \mathrm{ml})$ for 4 days, followed by restimulation with $2 \mu \mathrm{g} /$ $\mathrm{ml}$ reactive peptide mix for another $6 \mathrm{~h}$ in the presence of BFA for evaluation of intracellular cytokines. The cells were washed, incubated for $10 \mathrm{~min}$ at $4^{\circ} \mathrm{C}$ with anti-CD16/32 mAb (2.4G2, produced in house) to block $\mathrm{Fc} \gamma$ receptors, and stained with mAbs against surface molecules for $20 \mathrm{~min}$ at $4^{\circ} \mathrm{C}$. The cells were then fixed, permeabilized (Cytofix/Cytoperm; BD Biosciences), and stained with mAbs against cytokines. $1-3 \times 10^{5}$ live $\mathrm{CD} 3^{+}$cells were acquired on a BD LSR II Flow cytometer (BD Biosciences), and data were analyzed with FlowJo Software (TreeStar, San Carlos, CA).

\section{Cytokine ELISAs}

Single-cell suspensions were prepared from ear-infected draining LN. $5 \times 10^{5}$ cells/well (96-well round-bottom plates) were plated in the presence of $10 \mu \mathrm{g} / \mathrm{ml}$ SLA. Seventy-two hours later, the culture supernatant was harvested and IFN- $\gamma$ IL-4, and IL-10 production was evaluated by ELISA (eBioscience), following the manufacturer's instructions.

\section{Statistical Analysis}

Data were analyzed and charts were generated using Prism 5 GraphPad software (San Diego, CA). Comparisons between two groups were performed by unpaired Student's t-test. Comparisons between three or more groups were performed by one-way ANOVA analysis (multiple comparisons Tukey's post hoc test). P values $\leq 0.05$ were considered statistically different and labeled with a single asterisk $\left(^{*}\right)$, in contrast to $\mathrm{P}$ values of $\leq 0.01{ }^{(* *)}$ or $\leq 0.001{ }^{(* * *)}$.

\section{Supporting Information}

Figure S1 STI1 aa sequence alignment from $L$. major, L. infantum, L. donovani, and L. braziliensis. Amino acid sequences were predicted from cDNA sequences obtained from NCBI database (www.ncbi.nlm.nih.gov). Residues matching between different Leishmania species are shown in dark gray boxes. (TIF)

Figure S2 Quality control of anti-DEC mAb engineering to expressed distinct $L$. major antigens. (A) STI1 from $L$. major was divided into two fragments: the $\mathrm{N}$-terminal portion (aa 1-398, red, LmSTIla) and the C-terminal portion (aa 401-546, blue, LmSTI1b). Each fragment was cloned in frame into the $\mathrm{C}$ terminal domain of the heavy chain of anti-DEC mAb or a control Ig mAb without receptor affinity (represented in B, left diagram). Furthermore, a small peptide (aa 344-366, pink) was cloned in frame to the C-terminal domain of anti-DEC mAb after a short linker (represented in B, right diagram). (B) Diagrammatic representation of anti-DEC mAb conjugated with LmSTIla and LmSTI1b (left diagram) or with $\mathrm{LmSTI}_{344-366}$ (right diagram). (C) Coomassie blue-stained 10\% (vol/vol) SDS-PAGE reducing gel comparing fusion mAbs with the molecular mass in $\mathrm{kDa}$. (D) Western blotting of fusion mAbs using HRP-conjugated antimouse IgG1. Molecular mass is indicated in $\mathrm{kDa}$. (E) Binding of the fusion mAbs to their cognate receptor analyzed by FACS. CHO cells transfected to expressed mouse DEC (red) or control non-transfected CHO cells (CHO-NEO, blue) were incubated with graded doses $(0.02-2 \mu \mathrm{g})$ of fusion $\mathrm{mAb}$, followed by staining with PE-labeled anti-mouse IgG. (F) The N-terminal portion of LeIF (aa 1-226) was cloned in frame into the C-terminal domain of anti-DEC mAb or a control Ig mAb. (G) Panel shows Coomassie blue-stained SDS-PAGE as in C. (H) Panel shows Western blotting as explained in D. (I) FACS plots show binding to CHO cells expressing DEC as explained in E.

(TIF)

Figure S3 Multifunctional $\mathrm{CD4}^{+} \mathrm{T}$ cell responses are elicited by anti-DEC-LmSTI1a in Balb/c mice. Balb/c mice were intraperitoneally immunized with $1 \mu \mathrm{g}$ of anti-DECLmSTIla or control Ig-LmSTIla mAbs in the presence of $50 \mu \mathrm{g}$ poly ICLC and $25 \mu \mathrm{g}$ anti-CD40. Fourteen days later, splenocytes were restimulated in vitro with a reactive LmSTIla peptide mix in the presence of BFA for $6 \mathrm{~h}$. The production of IFN- $\gamma$, TNF- $\alpha$ and IL-2 was evaluated by FACS after intracellular cytokine staining, and the frequencies of $\mathrm{CD} 4^{+} \mathrm{IFN}-\gamma^{+} \mathrm{T}$ cells also producing TNF- $\alpha$ and/or IL-2 are shown as the mean $\pm \operatorname{SEM}(n=6)$.

(TIF)

Figure S4 Identification of LmSTI1a-, LeIF-, and LmSTI1b-CD4 $^{+} \mathbf{T}$ cell epitopes in Balb/c and G57BL/6 mice. Balb/c (A) or C57BL/6 (B) mice were immunized with anti-DEC-LmSTIla mAb in the presence of $50 \mu \mathrm{g}$ poly ICLC and $25 \mu \mathrm{g}$ anti-CD40 mAb. Two weeks later, splenocytes were restimulated with $2 \mu \mathrm{g} / \mathrm{ml}$ of the indicated individual LmSTIla peptide from pools 1,2 , and 8 . IFN- $\gamma$ production was evaluated by flow cytometry after intracellular cytokine staining, and the bars are shown as the mean $\pm \operatorname{SEM}(n=3)$. The aa sequence of the reactive peptides is shown. The sequences of the previously 
described reactive epitopes in Balb/c mice are underlined [37]. (G) Splenocytes from Balb/c mice immunized 14 days previously with anti-DEC-LeIF mAb plus adjuvant were restimulated with $2 \mu \mathrm{g} /$ $\mathrm{ml}$ of the indicated individual peptides from pool 5. IFN- $\gamma$ production was evaluated by flow cytometry after intracellular cytokine staining. Bars are shown as the mean $\pm \operatorname{SEM}(n=3)$, and the aa sequence of the reactive peptide is shown. (D) As in C, but animals were immunized with anti-DEC-LmSTIlb plus adjuvant. The sequence of a previously described reactive epitope in Balb/c mice is underlined [37].

(TIF)

Figure S5 Delivery of LmsTI1a to DGs using anti-DEG mAbs protects mice against cutaneous leishmaniasis. (A) $\mathrm{Balb} / \mathrm{c}$ mice were primed and boosted 1 month apart with $10 \mu \mathrm{g}$ of anti-DEC mAbs coupled with LACK, LeIF, or LmSTIla, or a control Ig-LmSTIla mAbs in the presence of $50 \mu \mathrm{g}$ of poly ICLC. Ten to 15 days after the last immunization, the mice were challenged with a single dose of 200-1000 L. major metacyclic promastigotes. Representative lesions in the ears of Balb/c mice 12 weeks after challenge are shown. (B) Balb/c mice were vaccinated in a prime-boost regimen consisting of two doses of $10 \mu \mathrm{g}$ of antiDEC or control Ig mAbs conjugated with either LmSTIla, LmSTIb, or LeIF, subcutaneously administered in the presence of poly ICLC $(50 \mu \mathrm{g})$ in the right footpad. Two weeks after the boost, the mice were subcutaneously challenged in the left footpad with $1-2 \times 10^{6}$ L. major metacyclic promastigotes. Vaccine efficacy was determined by weekly measurement of the thickness of the infected footpad. The mean \pm SEM is shown $(n \geq 4)$. $(\mathrm{C})$ As in $B$, but the number of parasites in the infected footpad is shown as the mean $\pm \operatorname{SEM}(\mathrm{n} \geq 4)$. n.d. $=$ not detected. (D) As in A, but C57BL/6 mice were primed and boosted 1 month apart with two subcutaneous doses of anti-DEC-LmSTIla $(1 \mu \mathrm{g})$ in the presence of $50 \mu \mathrm{g}$ of poly ICLC. Ten to 15 days after the last immunization, mice were challenged with a single dose of 200-1000 L. major

\section{References}

1. Kaye P, Scott P (2011) Leishmaniasis: complexity at the host-pathogen interface. Nat Rev Microbiol 9: 604-615.

2. Tripathi P, Singh V, Naik S (2007) Immune response to leishmania: paradox rather than paradigm. FEMS Immunol Med Microbiol 51: 229-242.

3. Sacks D, Noben-Trauth N (2002) The immunology of susceptibility and resistance to Leishmania major in mice. Nat Rev Immunol 2: 845-858.

4. Scott P, Artis D, Uzonna J, Zaph C (2004) The development of effector and memory $\mathrm{T}$ cells in cutaneous leishmaniasis: the implications for vaccine development. Immunol Rev 201: 318-338.

5. Reiner SL, Locksley RM (1995) The regulation of immunity to Leishmania major. Annu Rev Immunol 13: 151-177.

6. Launois P, Louis JA, Milon G (1997) The fate and persistence of Leishmania major in mice of different genetic backgrounds: an example of exploitation of the immune system by intracellular parasites. Parasitology 115 Suppl: S25-S32.

7. Berberich G, Ramirez-Pineda JR, Hambrecht C, Alber G, Skeiky YA, et al. (2003) Dendritic cell (DC)-based protection against an intracellular pathogen is dependent upon DC-derived IL-12 and can be induced by molecularly defined antigens. J Immunol 170: 3171-3179.

8. Olobo JO, Anjili CO, Gicheru MM, Mbati PA, Kariuki TM, et al. (1995) Vaccination of vervet monkeys against cutaneous leishmaniosis using recombinant Leishmania 'major surface glycoprotein' (gp63). Vet Parasitol 60: 199-212.

9. Rafati S, Nakhaee A, Taheri T, Taslimi Y, Darabi H, et al. (2005) Protective vaccination against experimental canine visceral leishmaniasis using a combination of DNA and protein immunization with cysteine proteinases type I and II of L. infantum. Vaccine 23: 3716-3725.

10. Sjolander A, Baldwin TM, Curtis JM, Bengtsson KL, Handman E (1998) Vaccination with recombinant Parasite Surface Antigen 2 from Leishmania major induces a Thl type of immune response but does not protect against infection. Vaccine 16: 2077-2084.

11. Mougneau E, Altare F, Wakil AE, Zheng S, Coppola T, et al. (1995) Expression cloning of a protective Leishmania antigen. Science 268: 563-566.

12. Coler RN, Reed SG (2005) Second-generation vaccines against leishmaniasis. Trends Parasitol 21: 244-249.

13. Murray HW, Berman JD, Davies CR, Saravia NG (2005) Advances in leishmaniasis. Lancet 366: 1561-1577. metacyclic promastigotes. The quantification of parasites obtained from the infected ears was determined 4 weeks after challenge. The mean \pm SEM is shown $(\mathrm{n}=4-5)$.

(TIF)

Figure S6 Cytokine profile from ear-infected draining LN cells stimulated in vitro with SLA after intradermal challenge with $L$. major. Total cell suspensions of ear-infected draining LN obtained from mice immunized with different preparations, as described in Figure 6, were restimulated in vitro for $72 \mathrm{~h}$ with $10 \mu \mathrm{g} / \mathrm{ml} \mathrm{SLA}$. IL-4 (A) and IFN- $\gamma(\mathrm{B})$ levels in the supernatants of the cultures were determined by ELISA. The cultures were set in triplicates, and the data shows the mean \pm SEM $(\mathrm{n} \geq 4)$.

(TIF)

Table S1 Peptide sequences covered by the immunogenic pools.

(DOC)

Table S2 Primers sequences.

(DOC)

\section{Acknowledgments}

All the authors read and approved the final manuscript, with the exception of Dr. Ralph Steinman, who passed away suddenly on September $30^{\text {th }}$, 2011. Most importantly, Dr. Steinman actively contributed to the design and realization of this work. The authors thank Marguerite Nulty for help with references; Jacqueline Chiappetta for administrative help; and Andres C. Gottfried, Marina Caskey, Kang Liu, and Christine Trumpfheller for critical reading of the manuscript.

\section{Author Contributions}

Conceived and designed the experiments: IM RMS JI. Performed the experiments: IM JI. Analyzed the data: IM JI. Contributed reagents/ materials/analysis tools: IM OM AL. Wrote the paper: IM JI.

14. Steinman RM (2007) Dendritic cells: versatile controllers of the immune system. Nat Med 13: 1155-1159.

15. Steinman RM, Banchereau J (2007) Taking dendritic cells into medicine. Nature 449: 419-426.

16. Pulendran B, Palucka K, Banchereau J (2001) Sensing pathogens and tuning immune responses. Science 293: 253-256.

17. Remer KA, Apetrei C, Schwarz T, Linden C, Moll H (2007) Vaccination with plasmacytoid dendritic cells induces protection against infection with Leishmania major in mice. Eur J Immunol 37: 2463-2473.

18. Ramirez-Pineda JR, Frohlich A, Berberich C, Moll H (2004) Dendritic cells (DC) activated by CpG DNA ex vivo are potent inducers of host resistance to an intracellular pathogen that is independent of IL-12 derived from the immunizing DC. J Immunol 172: 6281-6289.

19. Flohe SB, Bauer C, Flohe S, Moll H (1998) Antigen-pulsed epidermal Langerhans cells protect susceptible mice from infection with the intracellular parasite Leishmania major. Eur J Immunol 28: 3800-3811.

20. Soares H, Waechter H, Glaichenhaus N, Mougneau E, Yagita H, et al. (2007) A subset of dendritic cells induces CD $4^{+} \mathrm{T}$ cells to produce IFN-g by an IL-12independent but CD70-dependent mechanism in vivo. J Exp Med 204: 10951106.

21. Bonifaz LC, Bonnyay DP, Charalambous A, Darguste DI, Fujii S, et al. (2004) In vivo targeting of antigens to maturing dendritic cells via the DEC-205 receptor improves T cell vaccination. J Exp Med 199: 815-824.

22. Trumpfheller C, Finke JS, Lopez CB, Moran TM, Moltedo B, et al. (2006) Intensified and protective $\mathrm{CD} 4^{+} \mathrm{T}$ cell immunity in mice with anti-dendritic cell HIV gag fusion antibody vaccine. J Exp Med 203: 607-617.

23. Trumpfheller C, Longhi MP, Caskey M, Idoyaga J, Bozzacco L, et al. (2012) Dendritic cell-targeted protein vaccines: a novel approach to induce T-cell immunity. J Intern Med 271: 183-192.

24. Idoyaga J, Lubkin A, Fiorese C, Lahoud MH, Caminschi I, et al. (2011) Comparable T helper 1 (Th1) and CD8 T-cell immunity by targeting HIV gag p24 to CD8 dendritic cells within antibodies to Langerin, DEC205, and Clec9A. Proc Natl Acad Sci USA 108: 2384-2389.

25. Trumpfheller C, Caskey M, Nchinda G, Longhi MP, Mizenina O, et al. (2008) The microbial mimic poly $\mathrm{IC}$ induces durable and protective $\mathrm{CD} 4^{+} \mathrm{T}$ cell 
immunity together with a dendritic cell targeted vaccine. Proc Natl Acad Sci USA 105: 2574-2579.

26. Longhi MP, Trumpfheller C, Idoyaga J, Caskey M, Matos I, et al. (2009) Dendritic cells require a systemic type I interferon response to induce CD4 ${ }^{+} \mathrm{Th} 1$ immunity with poly IC as adjuvant. J Exp Med 206: 1589-1602.

27. Do Y, Park CG, Kang YS, Park SH, Lynch RM, et al. (2008) Broad T cell immunity to the LcrV virulence protein is induced by targeted delivery to DEC205/CD205-positive mouse dendritic cells. Eur J Immunol 38: 20-29.

28. Do Y, Didierlaurent AM, Ryu S, Koh H, Park CG, et al. (2012) Induction of pulmonary mucosal immune responses with a protein vaccine targeted to the DEC-205/CD205 receptor. Vaccine 30: 6359-6367.

29. Webb JR, Campos-Neto A, Skeiky YA, Reed SG (1997) Molecular characterization of the heat-inducible LmSTI1 protein of Leishmania major. Mol Biochem Parasitol 89: 179-193.

30. Webb JR, Kaufmann D, Campos-Neto A, Reed SG (1996) Molecular cloning of a novel protein antigen of Leishmania major that elicits a potent immune response in experimental murine leishmaniasis. J Immunol 157: 5034-5041.

31. Campos-Neto A, Webb JR, Greeson K, Coler RN, Skeiky YA, et al. (2002) Vaccination with plasmid DNA encoding TSA/LmSTI1 leishmanial fusion proteins confers protection against Leishmania major infection in susceptible $\mathrm{BALB} / \mathrm{c}$ mice. Infect Immun 70: 2828-2836.

32. Coler RN, Skeiky YA, Bernards K, Greeson K, Carter D, et al. (2002) Immunization with a polyprotein vaccine consisting of the T-Cell antigens thiolspecific antioxidant, Leishmania major stress-inducible protein 1, and Leishmania elongation initiation factor protects against leishmaniasis. Infect Immun 70: 4215-4225.

33. Coler RN, Goto Y, Bogatzki L, Raman V, Reed SG (2007) Leish-111f, a recombinant polyprotein vaccine that protects against visceral Leishmaniasis by elicitation of CD4+ T cells. Infect Immun 75: 4648-4654

34. Velez ID, Gilchrist K, Martinez S, Ramirez-Pineda JR, Ashman JA, et al. (2009) Safety and immunogenicity of a defined vaccine for the prevention of cutaneous leishmaniasis. Vaccine 28: 329-337.

35. Darrah PA, Patel DT, De Luca PM, Lindsay RW, Davey DF, et al. (2007) Multifunctional $\mathrm{T}_{\mathrm{H}} 1$ cells define a correlate of vaccine-mediated protection against Leishmania major. Nat Med 13: 843-850.

36. Macedo AB, Sanchez-Arcila JC, Schubach AO, Mendonca SC, Marins-DosSantos A, et al. (2012) Multifunctional CD4 T cells in patients with American cutaneous leishmaniasis. Clin Exp Immunol 167: 505-513.

37. Bertholet S, Goto Y, Carter L, Bhatia A, Howard RF, et al. (2009) Optimized subunit vaccine protects against experimental leishmaniasis. Vaccine 27: 70367045.

38. Skeiky YA, Kennedy M, Kaufman D, Borges MM, Guderian JA, et al. (1998) LeIF: a recombinant Leishmania protein that induces an IL-12-mediated Th1 cytokine profile. J Immunol 161: 6171-6179.

39. Launois P, Maillard I, Pingel S, Swihart KG, Xenarios I, et al. (1997) IL-4 rapidly produced by $\mathrm{Vb} 4 \mathrm{Va} 8 \mathrm{CD} 4+\mathrm{T}$ cells instructs $\mathrm{Th} 2$ development and susceptibility to Leishmania major in BALB/c mice. Immunity 6: 541-549.

40. Larregina AT, Falo LD, Jr. (2005) Changing paradigms in cutaneous immunology: adapting with dendritic cells. J Invest Dermatol 124: 1-12.

41. Romani N, Thurnher M, Idoyaga J, Steinman RM, Flacher V (2010) Targeting of antigens to skin dendritic cells: possibilities to enhance vaccine efficacy. Immunol Cell Biol 88: 424-430.

42. Launois P, Tacchini-Cottier F, Kieny MP (2008) Cutaneous leishmaniasis: progress towards a vaccine. Expert Rev Vaccines 7: 1277-1287.

43. Ghosh M, Pal C, Ray M, Maitra S, Mandal L, et al. (2003) Dendritic cell-based immunotherapy combined with antimony-based chemotherapy cures established murine visceral leishmaniasis. J Immunol 170: 5625-5629.

44. Wang B, Zaidi N, He LZ, Zhang L, Kuroiwa JM, et al. (2012) Targeting of the non-mutated tumor antigen HER2/neu to mature dendritic cells induces an integrated immune response that protects against breast cancer in mice. Breast Cancer Res 14: R39.

45. Hemmi H, Zaidi N, Wang B, Matos I, Fiorese C, et al. (2012) Treml4, an Ig superfamily member, mediates presentation of several antigens to T cells in vivo, including protective immunity to HER2 protein. J Immunol 188: 1147-1155.
46. Campos-Neto A, Porrozzi R, Greeson K, Coler RN, Webb JR, et al. (2001) Protection against cutaneous leishmaniasis induced by recombinant antigens in murine and nonhuman primate models of the human disease. Infect Immun 69: 4103-4108.

47. Chakkalath HR, Theodos CM, Markowitz JS, Grusby MJ, Glimcher LH, et al, (1995) Class II major histocompatibility complex-deficient mice initially control an infection with Leishmania major but succumb to the disease. J Infect Dis 171: 1302-1308.

48. Gurunathan S, Prussin C, Sacks DL, Seder RA (1998) Vaccine requirements for sustained cellular immunity to an intracellular parasitic infection. Nat Med 4: 1409-1415.

49. Melby PC, Yang J, Zhao W, Perez LE, Cheng J (2001) Leishmania donovan p36(LACK) DNA vaccine is highly immunogenic but not protective against experimental visceral leishmaniasis. Infect Immun 69: 4719-4725.

50. Skeiky YAW, Guderian JA, Benson DR, Bacelar O, Carvalho EM, et al. (1995) A recombinant Leishmania antigen that stimulates human peripheral blood mononuclear cells to express a Th1-type cytokine profile and to produce interleukin 12. J Exp Med 181: 1527-1537.

51. Nascimento E, Fernandes DF, Vieira EP, Campos-Neto A, Ashman JA, et al. (2010) A clinical trial to evaluate the safety and immunogenicity of the LEISHF1+MPL-SE vaccine when used in combination with meglumine antimoniate for the treatment of cutaneous leishmaniasis. Vaccine 28: 6581-6587.

52. Reis e Sousa C, Hieny S, Scharton-Kersten T, Jankovic D, Charest H, et al. (1997) In vivo microbial stimulation induces rapid CD40L-independent production of IL-12 by dendritic cells and their re-distribution to T cell areas. J Exp Med 186: 1819-1829.

53. Hochrein H, Shortman K, Vremec D, Scott B, Hertzog P, et al. (2001) Differential production of IL-12, IFN-a, and IFN-g by mouse dendritic cell subsets. J Immunol 166: 5448-5455.

54. Kastenmuller K, Espinosa DA, Trager L, Stoyanov C, Salazar AM, et al. (2013) Full-length Plasmodium falciparum circumsporozoite protein administered with long-chain poly(I.C.) or the Toll-like receptor 4 agonist glucopyranosyl lipid adjuvant-stable emulsion elicits potent antibody and CD4+ T cell immunity and protection in mice. Infect Immun 81: 789-800.

55. Caskey M, Lefebvre F, Filali-Mouhim A, Cameron MJ, Goulet JP, et al. (2011) Synthetic double-stranded RNA induces innate immune responses similar to a live viral vaccine in humans. J Exp Med 208: 2357-2366.

56. Ponte-Sucre A, Heise D, Moll H (2001) Leishmania major lipophosphoglycan modulates the phenotype and inhibits migration of murine Langerhans cells. Immunology 104: 462-467.

57. Mauel J (1990) Macrophage-parasite interactions in Leishmania infections. J Leukoc Biol 47: 187-193.

58. Kraal G, Breel M, Janse M, Bruin G (1986) Langerhans cells, veiled cells, and interdigitating cells in the mouse recognized by a monoclonal antibody. J Exp Med 163: 981-997.

59. Jiang W, Swiggard WJ, Heufler C, Peng M, Mirza A, et al. (1995) The receptor DEC-205 expressed by dendritic cells and thymic epithelial cells is involved in antigen processing. Nature 375: 151-155.

60. Hawiger D, Inaba K, Dorsett Y, Guo M, Mahnke K, et al. (2001) Dendritic cells induce peripheral $\mathrm{T}$ cell unresponsiveness under steady state conditions in vivo. J Exp Med 194: 769-780.

61. Mossessova E, Lima CD (2000) Ulp1-SUMO crystal structure and genetic analysis reveal conserved interactions and a regulatory element essential for cell growth in yeast. Mol Cell 5: 865-876.

62. Aida Y, Pabst MJ (1990) Removal of endotoxin from protein solutions by phase separation using Triton X-114. J Immunol Methods 132: 191-195.

63. Sacks DL, Hieny S, Sher A (1985) Identification of cell surface carbohydrate and antigenic changes between noninfective and infective developmental stages of Leishmania major promastigotes. J Immunol 135: 564-569.

64. Titus RG, Marchand M, Boon T, Louis JA (1985) A limiting dilution assay for quantifying Leishmania major in tissues of infected mice. Parasite Immunol 7: $545-555$. 